\title{
HISTORICAL MACROECONOMICS AND AMERICAN MACROECONOMIC HISTORY
}

Charles W. Calomiris

Christopher Hanes

Working Paper No. 4935

\author{
NATIONAL BUREAU OF ECONOMIC RESEARCH \\ 1050 Massachusetts Avenue \\ Cambridge, MA 02138 \\ November 1994
}

The authors thank Barry Eichengreen, Kevin Hoover, Robert Margo, Allen Meltzer, Kenneth Snowden, and Peter Temin for helpful discussions. This paper will appear as a chapter in Kevin Hoover, ed., Macroeconometrics: Developments, Tensions and Prospects, Boston: Kluwer Academic Publishers. This paper is part of NBER's programs in Development of the American Economy and Economic Fluctuations. Any opinions expressed are those of the authors and not those of the National Bureau of Economic Research.

(c) 1994 by Charles W. Calomiris and Christopher Hanes. All rights reserved. Short sections of text, not to exceed two paragraphs, may be quoted without explicit permission provided that full credit, including $\odot$ notice, is given to the source. 


\section{HISTORICAL MACROECONOMIC AND AMERICAN MACROECONOMIC HISTORY}

\section{ABSTRACT}

What can macroeconomic history offer macroeconomic theorists and macroeconometricians? Macroeconomic history offers more than longer time series or special "controlled experiments." It suggests an historical definition of the economy, which has implications for macroeconometric methods. The defining characteristic of the historical view is its emphasis on "path dependence": ways in which the cumulative past, including the history of shocks and their effects, change the structure of the economy. This essay reviews American macroeconomic history to illustrate its potential uses, and to draw out methodological implications.

"Keynesian" models can account for the most obvious cycle patterns in all historical periods, while "new classical" models cannot. Nominal wage rigidity was important historically and some models of wage rigidity receive more support from history than others. A shortcoming of both Keynesian and new-classical approaches is the assumption that low-frequency change is exogenous to demand. The history of the Kuznets cycle illustrates how aggregate-demand shocks can produce endogenous changes in aggregate supply. Economies of scale, learning effects, and convergences of expectations -- many within the spatial contexts of city building and frontier settlement -- seem to have been especially important in making the aggregate supply "pathdependent." Institutional innovation (particularly government regulation) has been another source of endogenous change in aggregate supply.

The historical view's emphasis on endogenous structural change points in the direction of a greater use of panel and cross-section analysis over short sample periods to identify the sources and consequences of macroeconomic shocks.

Charles W. Calomiris

Department of Finance

University of Illinois at Urbana-Champaign

340 Commerce West

Champaign, IL 61820 and NBER
Christopher Hanes

Department of Economics

University of Pennsylvania

3718 Locust Walk

Philadelphia, PA 19104 


\section{INTRODUCTION}

We take macroeconometrics to be the application of statistical models to questions posed by macroeconomic theory. Macroeconomic facts and theories relate to two sets of issues usually viewed as separable: long-term variations in economic growth across decades and/or countries; and short-term (highfrequency) variations in employment and output - usually referred to as business cycles. Empirical research can help one judge among competing theories and can establish facts that join the list of patterns to be explained by new theories.

The vast majority of macroeconometric studies rely on data for the period since the Second World War. There can be good reasons for focussing only on postwar data: some data useful for describing the macroeconomy and discriminating among macroeconomic theories were not collected in earlier years, or were collected in less reliable ways. What can macroeconomic history - the study of the macroeconomy before World War II - offer to macroeconomists and macroeconometricians? History may offer some opportunities to apply macroeconomic theory to explain events that are interesting in themselves - the Great Depression, for example. But that is merely a matter of applying macroeconomic theory and empirical methods to history, not using history to inform macroeconomics or macroeconometrics. Our focus in this essay is to highlight the factual, theoretical, and econometric implications of historical research on American business cycles.

Sometimes the past has been used simply to extend time series data to permit tests of questions of current interest. The data and methods of such studies will change over time as new paradigms are introduced by macroeconomists. Perhaps the most famous and influential example of this approach is Friedman and Schwartz's (1963) Monetary History of the United States. This was arguably the first and most influential test of the monetarist proposition that money and nominal income are closely related. The authors' argument was based largely on the robustness of the association over a long span of time. ${ }^{1}$ More recently, macroeconomists in search of longer time series have turned to historical data to resolve debates between the "new Keynesian" and "new classical" schools, which often translate into debates about the cyclical properties of wages, prices, and technological change. 
In some cases, macroeconomists have been drawn to particular data from historical periods because those data are of better quality than any postwar data on the same subject - for example, surveys of wage rate changes from the 1890 s and 1930 s (as we discuss below). More importantly, some interwar and prewar events may constitute shocks to the economy that are more dramatic, and possibly more informative, than any shocks that occurred in the postwar period. The Great Depression is a case in point. As Milton Friedman noted long ago, "The major defect of the data on which economists must rely - data generated by experience rather than deliberately contrived experiment - is the small range of variation they encompass" (1952, p. 612).

The past can also be useful as a source of unique "historical experiments" that can shed light on questions of current interest to macrotheorists or policy makers. For example, Calomiris and Hubbard (1994a) use observed marginal tax rates paid by firms subject to the short-lived undistributed profits tax of 1936-1937 (which taxed retained earnings with a progressive marginal tax schedule) to measure the shadow cost of external finance to firms, and to show how differences in the shadow cost of finance affect investment behavior. Some of history's natural experiments take on new importance in light of later experience and policy issues. The high-inflation episodes of the 1970 s renewed interest in past experiences with hyperinflation, and in the question of whether policy regime changes in the past that ended high inflation were associated with major contractions in real activity (Sargent, 1981a, 1981b). During the 1980s, controversies over rising federal deficits prompted new research on extreme historical examples of high deficits in the past and their links to inflation and interest rates (Smith, 1985a, 1985b, Calomiris, 1988a, 1988b, Evans, 1985, Barro, 1987).

But we will argue that macroeconomic history offers more than long strings of data and special examples. It suggests an historical definition of the macroeconomy, which has important implications for macroeconometric methods. Historical macroeconomics is not the application of standard macroeconomic tools to data from the distant past, or the selective exploration of the past to discover interesting experiments; it is "thinking historically" about macroeconomic change - an alternative approach to 
analyzing data both from the recent and distant past. ${ }^{2}$

The defining characteristic of the historical view of the macroeconomy is its emphasis on "pathdependence. ${ }^{\text {m3 }}$ Historical path dependence does not refer to the serial correlation properties of time series data. Indeed, the historical view runs counter to the mainstream macroeconomist's interpretation of historical time series as the realizations of a changing, but essentially homogeneous, stochastic process resulting from optimization rules that relate macroeconomic outcomes to exogenous changes in utility functions, endowments, and information sets of agents. Mainstream macroeconometric studies assume that variations in data are generated by exogenous shocks acting on a fixed macroeconomic structure. Patterns in the data can reveal the nature of that structure, including the values of its underlying parameters. The structure may change over time, but that structural changes occur independently of the exogenous shocks. Historical path dependence, in contrast, explores ways in which the cumulative past of the economy, including the history of shocks and their effects, change the structure of the economy.

Path dependence manifests itself in a variety of ways: decision rules change as a result of learning; institutional innovations (private and public) change the constraints of agents. Some events have permanent importance for the future of the economy through their influence on the way decision rules and institutions change.

"Structural" differences between today's economy and the economies of the past - which are sometimes viewed as a reason to avoid historical data - are in fact what make historical data uniquely useful to macroeconomists. The features that make up the modern economy - everything from the body of knowledge that constitutes "technology" to the rules and behaviors that define "institutions" developed over time. If understanding and taking account of such structural change is part of the job of macroeconomics - and we believe it is - then there is no avoiding the past.

Given the tenets of the historical view of the macroeconomy, it is not surprising that "macrocliometricians" often ask different questions than their "mainstream" counterparts and use different methods to answer those questions. In particular, they explore the origins of institutional change (the 
particular events that result in change), and measure the consequences of these changes. This often requires looking closely at specific moments, and relying on panel data and cross-sections, analysis of nonquantitative information, and good story-telling, rather than long strings of time series to argue a point.

Our goals in this essay are two: First, we provide a selective review of American macroeconomic history to illustrate the potential uses of historical data for a variety of purposes - to increase sample size for testing models, to address questions of current interest with unique experiments from the past, and to demonstrate the uses of the historical view of the economy (in particular, the importance of institutional change). Second, we emphasize and draw out methodological issues that arise in these examples and their implications for econometric modeling.

Our review of American macroeconomic history begins with section II's overview of the salient facts about the U.S. macroeconomy during the nineteenth and twentieth centuries, which focusses on continuity and change in patterns of covariation among macroeconomic time series. Section III discusses the uses of these and other data for discriminating among models of high-frequency macroeconomic fluctuations. We focus on uses of historical data to distinguish between "new Keynesian" and "new classical" paradigms, and to distinguish among new Keynesian explanations for wage and price rigidities. We argue that Keynesian models can account for the most obvious cyclical patterns in macroeconomic variables in all historical periods, while "new classical" models cannot. New classical models are also inconsistent with historical evidence on the nature of technological change. It seems unlikely, therefore, that historical data will prove to offer much support for real business cycle theory, at least in its current form. We also argue that nominal wage rigidity (which has been de-emphasized by macroeconomists in response to the "Barro critique") was important historically in generating layoffs, and that some models of nominal wage rigidity and its allocative costs receive more support from history than others.

With respect to low-frequency fluctuations, neither the new-classical emphasis on exogenous technological change, nor Keynesian nominal rigidities offers a complete account. Here historical evidence can be particularly useful for defining the interesting unit of observation (the "Kuznets cycle") 
and pointing to plausible explanations for "long swings" by focusing on common historical patterns (city building, frontier settlement, waves of immigration, and endogenous technological change).

Section IV discusses evidence of the importance of institutions, regulations, and beliefs for macroeconomic outcomes and considers how important changes in these variables have occurred, using the Great Depression as an example. Section V concludes.

From the standpoint of the methodological lessons we seek to draw out of our review, each of these sections makes distinct but related points. Section II focuses on problems of constructing consistent time series over long periods of time, and analyzing those data in the presence of shifting historical regimes (particularly, shifts in the time series process of prices). Sections III and IV criticize both prominent macroeconometric frameworks for ignoring sets of facts inconsistent with their models - in particular, we emphasize the failure of real business cycle theorists to consider historical evidence on the pace of technological innovation and diffusion, and the failure of neo-Keynesian macroeconomists to come to grips with "long swings" in the economy.

In both cases, those shortcomings are reflected in assumptions about the identification of supply and demand shocks in the economy. Both Keynesian and new-classical approaches share the tendency to view low-frequency change as exogenous to demand - an assumption grossly at odds with the historical literature on the Kuznets cycle. The history of the Kuznets cycle is largely a history of aggregate demand shocks that produced endogenous changes in aggregate supply. Economies of scale, learning effects, and convergences of expectations - many within the spatial contexts of city building and frontier settlement seem to have been especially important. Put differently, aggregate supply historically has been "pathdependent."

Once one begins to focus on low-frequency changes and on the persistent effects of particular events and shifts in institutional regimes, other methodological criticisms follow. First, the true number of observations in time series data may be smaller than annual time series data suggest. Second, the occupation of estimating the parameters of a supposedly fixed economic "structure" with long runs of 
time-series data is of questionable value. This can be thought of as a more general version of the so-called "Lucas critique" (Lucas, 1976): the economy's "fundamentals" as well as agents' expectations change with experience. Third, alternative approaches to testing macroeconomic models - those which exploit crosssectional variation as well as time-series variation - may be desirable. Panel or cross-sectional studies are useful both as a means to isolate spatial or sectoral characteristics of relevance to the history of long swings, and as a means to gain numbers of observations without assuming structural constancy over long periods of time.

\section{THE CYCLICAL BEHAVIOR OF MACROECONOMIC VARIABLES}

As of ten years ago, most research had indicated two big historical changes in cyclical patterns. First, output and employment were much less volatile after the Second World War than before the First World War or in the interwar period. Second, nominal wages and prices were less "flexible" in the postwar period than in earlier periods, in the sense that wage and price inflation had become were less sensitive to deviations from trend in output and employment levels. This evidence was cited to support theoretical conclusions and even recommendations for policy (for an example see DeLong and Summers, 1986). Since then careful attention to the nature of historical time-series has somewhat modified these stylized facts.

\section{Cyclical Volatility of Output and Employment}

Comparisons between historical periods require series that are consistent across the periods: constructed in the same way from the same kinds of data. Otherwise one may mistake differences in the way the series were constructed for changes over time in economic behavior. If consistent data are not available one must take account of the inconsistencies and adjust one's conclusions accordingly. Economists largely ignored this point until Christina Romer (1986a, 1986b) asserted that standard output and employment series for the late nineteenth and early twentieth centuries had been constructed in ways 
that "exaggerated" cyclical movements. Romer accepted the conventional wisdom that the Great Depression had been much more severe than any postwar cycle, but she argued that otherwise "the relative stabilization of the postwar economy is a figment of the data...the severity of economic fluctuations on both sides of the Great Depression are roughly equal" (1986b, p. 333).

Others have challenged Romer's results (for a review, see Zarnowitz, 1992, Chapter 3). David Weir $(1986,1992)$ concluded: "To the simple question of whether cyclical fluctuations around trend in GNP and unemployment have become smaller since World War II the data are more than adequate to deliver a definitive answer: yes" (1986, p. 365). Nathan Balke and Robert Gordon (1989) constructed historical series for real GNP that indicate "substantially greater volatility before 1929 than after 1946" (p. 81). The standard deviation of deviation from trend in the $\log$ of the series is about seventy per cent greater over 1869-1908 or 1869-1928 than in postwar periods. Indeed, Romer's own prewar real GNP series (1989) is more volatile than the postwar series, with a standard deviation of deviation from trend that is thirty per cent greater over 1869-1928 than 1947-1985. In Romer's view this means the prewar series is "only slightly more volatile" than the postwar data (p. 35). Others might judge the difference to indicate an important stabilization of output.

Unfortunately, no employment or GNP series for prewar years can be truly comparable to postwar series. Annual data on many sectors of the economy were simply not collected before the 1920 s. Historical estimates must be built on debatable assumptions. In the words of Susan Carter and Richard Sutch (1990), the process is like "inferring the shape of some long-extinct animal from bones collected in an ancient tar pit" (p. 294). It appears unlikely that we will reach a consensus any time soon. One might put more faith in results using data that are more consistent and directly comparable, if less comprehensive. Romer (1986b) compares the behavior of the best prewar series on industrial production, Edwin Frickey's index of manufacturing output (1947), to a couple of very similar postwar series on industrial production. She finds the standard deviation of deviation from trend to be ten to fourteen per cent greater over 1866-1914 than 1947-82 - a clear decrease in volatility but smaller than that indicated by anyone's real GNP series. 
The difference between results from series on real GNP and industrial production raises an issue that has been more or less ignored in the literature. Simon Kuznets (1951) observed that sectors vary in their sensitivity to business cycles. The cyclical behavior of aggregate output and employment might change over time as a result of shifts in the relative importance of different sectors, even if "there are no marked secular shifts within each sector in responsiveness to business cycles...For example, a decline in the weight of agriculture, combined with a lack of responsiveness of agricultural output to business cycles, would mean, other conditions being equal, a widening of business cycle amplitudes" (p. 159). It made sense to, focus on agriculture, for National Bureau researchers like Wesley Mitchell and Arthur Burns had found farming to be a uniquely acyclical sector: "the basic industry of growing crops does not expand and contract in unison with mining, manufacturing, trading, transportation, and finance" (Mitchell, 1951, p. 56). Farm output and employment "undergo cyclical movements, but they have little or no relation to business cycles" (Burns, 1951, pp. 7, 8). This was especially obvious in the interwar period. From 1930 to 1932 employment fell in every non-agricultural sector, including trade and services. Aggregate employment fell by 14 per cent. Meanwhile farm employment increased by 3 per cent. ${ }^{4}$ But it was also true before the First World War. Edwin Frickey found that from the 1870s through 1914 "agricultural production patterns traced out short-term fluctuations bearing little resemblance to those for other major production groups. The causal relationships between the agricultural and non-agricultural groups certainly did not express themselves in the form of any simple correlation" (1942, p. 229). This is not to say that agricultural incomes are acyclical; that depends on the cyclical pattern in the relative price of farm output.

As Table 1 shows, the twentieth century saw an enormous shift of resources out of agriculture, while the share of manufacturing in employment or output did not fall until the 1970 s. Most of the balance went to services. Services output and employment are less cyclical than manufacturing but more cyclical than agriculture. By itself, the sectoral shift should have tended to decrease the cyclicality of nonagricultural GNP, but increase the cyclicality of real GNP including agriculture. Both the Romer and Balke and Gordon series for real GNP purport to measure the latter. It seems odd that both indicate a 
larger decline in volatility than the consistent manufacturing production series examined by Romer.

Suppose, however, that one had reliable historical series for both real GNP and manufacturing output. Which would be appropriate to indicate changes in cyclical behavior? In comparing cyclical "volatility" over long periods, should one hold sectoral weights fixed, or equivalently, look at individual sectors? This issue is especially important for comparisons of cyclical volatility across different periods within the nineteenth century, before and after the War Between the States, for example. John James (1993) found that Robert Gallman's unpublished real GNP series (described in Gallman, 1960) indicates "a substantial increase in the degree of business-cycle severity or economic fluctuations" (p. 710) from 1834-1859 to 1869-1909. Calomiris and Hanes (1994) show that consistent series on industrial production are if anything less volatile in the postbellum period. These two results are not necessarily inconsistent with each other: given the rapid growth of manufacturing relative to agriculture over the nineteenth century, it is quite possible that real GNP became more volatile even as manufacturing output became less volatile.

Historical changes in the timing of business cycles - duration from peak to trough, and trough to peak - have also been the subject of recent studies. Francis Diebold and Glenn Rudebusch (1992) show that the standard NBER chronology suggests "a postwar shift toward longer expansions and shorter contractions" (p. 1003) with "no evidence for a postwar shift in the distribution of whole-cycle durations." Geoffrey Moore and Victor Zarnowitz (1986) made the same observation, but noted that the comparison was tricky because the NBER peak-trough dates for the prewar period were not chosen in the same way as interwar and postwar dates. Mark Watson (1994) and Christina Romer (1994) present evidence that the change in timing of NBER cycles indeed reflects changing definitions rather than changing economic behavior. Consistent data show contractions and expansions of about the same length in both the prewar and postwar periods.

Overall, the conclusion to draw from these various studies seems to be that business cycle severity has fallen over time while the duration and frequency of cycles has not significantly changed across 
historical eras, excluding the interwar period. The extent of the decline in cycle variance depends on assumptions both about how to measure output comparably over time, and whether to focus on manufacturing or the whole economy.

\section{Cyclical Movements in Nominal Wages and Prices}

The cyclical behavior of nominal wages or prices is often described in terms of a "Phillips curve": an estimated relation between the rate of change of wages (prices) and the current (or recent) output or employment level, given the rate of change of wages (prices) in the recent past. The relation is often assumed to be linear, giving an estimated coefficient on output or employment and a coefficient on lagged inflation. A number of studies compared prewar and postwar periods using the standard real GNP or employment series criticized by Romer and various series for wages and/or prices, including Albert Rees' (1961) series for average hourly earnings in manufacturing over 1890-1914, GNP deflators and wholesale price series. Most studies found smaller coefficients on output and larger coefficients on lagged inflation in the postwar period, concluding that there had been a decrease over time in cyclical "flexibility" (Cagan, 1975, Sachs, 1980). More recently, Steven Allen (1992) has shown that the Rees earnings series have a strong procyclical bias as a measure of true average hourly earnings. Taking account of that bias, Allen found an increase in the coefficient on lagged inflation but "no discernable change in the response of nominal wages to the output gap." Hanes (1993) found a similar pattern using consistent data on wage rates rather than hourly earnings. Robert Gordon (1990) observed a similar pattern in prices, as measured by a newly-constructed GNP deflator. "The sole change between pre-World War I and post-World War II was an increase in the inertia coefficient" (p. 1130), that is, the coefficient on lagged inflation.

Some studies have described price behavior in other terms. David Backus and Patrick Kehoe (1992) measure the relation between deviation from trend in output and deviation from trend in the price level. They find that the price level is procyclical over 1869-1914 and 1920-1939, and countercyclical over 1950-1983. Thomas Cooley and Lee Ohanian (1991) observe the same pattern, and also estimate the 
correlation between the rate of price inflation and the rate of growth in output. The latter is positive over $1870-1900$ and 1900-1946, negative over 1949-1975.

Table II reproduces the general results of these studies using standard wholesale price indices (that constructed by Warren and Pearson, 1932, linked to the BLS "All items" index) and the most consistent output series, the Frickey index and the Federal Reserve Board Materials Production Index (Romer, 1986b), to compare 1869-1914 and 1949-1990. Trends are defined using the Hodrick-Prescott filter (following Kydland and Prescott, 1990). We omit the interwar period because there is no clearly consistent output series to compare it with both of the others. Several studies have suggested that price behavior was very unusual in the oil shock of the early 1970 s, so we also present results excluding 1974 from the postwar sample. Specification (1) shows the pattern found by Allen, Gordon, and Hanes: the Phillips-curve coefficient on output deviation from trend is stable but that on lagged inflation increases considerably. (2) shows the pattern found by Backus and Kehoe and Cooley and Ohanian: price and output deviations from trend are positively correlated in the early period, negatively correlated in the later period. (3) shows the pattern found by Cooley and Ohanian: change in inflation and change in output are positively related in the early period, negatively related in the later period. The postwar correlation between inflation and output growth is very weak and becomes positive if 1974 is excluded from the sample. None of the other results are much affected when 1974 is excluded.

Some of the seemingly contradictory conclusions drawn by these studies can be reconciled by distinguishing price-output correlation from inflation-output correlation. As Alogoskoufis and Smith (1991), Allen (1992), and Obstfeld (1993, 242-246) point out, changes in the persistence of the inflation process will be reflected in a reduced sensitivity of inflation to the output gap, but this does not imply a reduced correlation between the output gap and the level of wages or prices. Allen judges that the stability in his Phillips curve output coefficient indicates that "wages 100 years ago were no more sensitive to the business cycle than they are today" (1992, p. 137). That conclusion may be correct with respect to wage level adjustment, but the increase in the persistence of inflation reflected in the coefficient on lagged price 
change implies a considerable decrease in the response of inflation to a cyclical downturn. Specification (4) demonstrates this point, showing that the ratio of the change in inflation to the change in the output deviation in NBER downturns. (Dates are taken from Moore and Zarnowitz, 1986.) The ratio is much smaller in the later period, even excluding 1974.

Cooley and Ohanian interpret the observed weakness of the association between inflation and output growth to imply the absence of a correlation between the change in the rate of inflation and the output gap, and hence they argue their results are inconsistent with the notion of a Phillips curve. In fact, that is not the case. Specification (5) shows that the correlation between the change in inflation and output deviation is in fact positive in both periods. The correlation is larger in the later period - from a Phillips-curve point of view, an artifact of constraining the coefficient on lagged inflation to be one.

A few studies have used changes in the Phillips curve to measure changes in the covariation of output with wage and price changes within the prewar period, rather than between the prewar and postwar periods. Hanes (1993) presents evidence of a change around 1890: the Phillips-curve coefficient on output is larger and the coefficient on lagged inflation is smaller in the 1870 s and 1880 s than the 1890 s and 1900s. Hanes' result is consistent with James' (1989) study of price behavior over 1837 to 1909: "the American economy earlier characterized by rapid (or instantaneous) price adjustment to clear markets evolved into one marked by gradual price adjustment (and one in which markets do not clear instantaneously) in the last part of the 19th century...the movement toward increasingly sluggish price adjustment was most pronounced between 1880 and 1890" (p.126).

But historical patterns of output-price correlations over time are clearer to document that to interpret. Despite the tendency in many studies to use Phillips curve coefficients to measure wage and price rigidity, we argue below that this is not a straightforward exercise. In particular, there are many pitfalls in inferring wage and price setting behavior from Phillips curve coefficients, and in using Phillips curves to measure the unemployment consequences of wage and price rigidity. 


\section{Cyclical Patterns in Other Variables}

Backus and Kehoe (1992) measure historical patterns in a number of other variables for the United States and some other countries, comparing prewar, interwar and postwar periods. For all countries, in all periods, consumption appears "uniformly procyclical" and investment is "strongly procyclical." Net exports have "generally been countercyclical"; for the United States net exports appear countercyclical in all periods.

Bernanke and Powell (1986) compare the cyclical behavior of employment, weekly hours, average hourly earnings and physical labor productivity in a fixed set of industries across the interwar and postwar periods. They find that: "The interrelation of productivity, hours, output, and employment is essentially stable between the prewar and postwar periods" (p. 597), though they do observe "an increased reliance in the postwar period on layoffs, rather than short workweeks, as a means of reducing labor input". The real consumption value of hourly earnings - an imperfect measure of "real wages" - was "procyclical (essentially coincident) in the postwar period but 'half out of phase' (usually lagging) in the prewar" (p. 617). They find no change in the cyclical behavior of labor productivity. "Procyclical labor productivity..appears to be present in every industry, in both..periods" (p. 617). The lack of comparable employment data makes it hard to say whether labor productivity was also procyclical before 1919 . Some evidence suggests that labor productivity was not procyclical over the depression of the 1890 s (Weir, 1986, Carter and Sutch, 1990).

Cyclical patterns in a few other variables are of particular interest for our discussion below. One is the rate at which a domestic producer could exchange output for foreign goods, that is, the terms of international trade net of domestic tariffs. Robert Lipsey (1963) presents an annual series of terms of trade for the United States beginning in 1879. Unfortunately the series is not a true index; it is based on values per unit in fairly broad categories of goods and thus affected by variations in the composition of goods as well as prices (p. 93). In the postwar period terms of trade excluding tariffs can be roughly measured by the GNP deflator for exports divided by that for imports; these series begin with 1959. Tariff 
rates are even more of a problem, since the usual measure, tariff revenue divided by the value of imports, varies with shifts among commodities as well as changes in rates. Indices of tariff rates for interwar years have been constructed by E. Lerdau (1957) and Mario Crucini (1994). Crucini presents indices with both fixed and changing commodity weights. There are no tariff rate series for earlier years, but we may at least note that Frank Taussig (1931) describes no general rate changes preceding prewar downturns.

We regress the terms of trade gross or net of tariffs on industrial production, with both expressed as deviations of logs from the Hodrick-Prescott trend. Results are in Table III. In the prewar period the terms of trade are procyclical but the relation is not very strong. In the interwar period the terms of trade excluding tariffs are strongly countercyclical. The difference between the prewar and interwar periods was noted by Lipsey:

In the short-run behavior of U.S. terms of trade, a sharp shift may be noted. In the prewar years..they moved with prices and were roughly inverse to the terms of trade of the U.K. and [industrialized Europe]..After World War I, when U.S. terms of trade became inverse to price changes, they conformed well to both British and [European] terms of trade. It might be said that the trade pattern matured, developing from one that is characteristic of a primary goods exporter to one characteristic of a nation exporting manufactured products (p. 15).

In the postwar period terms of trade excluding tariffs are weakly procyclical if 1974 (the year of the oil price shock) is included in the sample, otherwise weakly countercyclical. The interwar pattern in terms of trade including tariffs depends on the tariff index. Using Lerdau's index they appear weakly countercyclical; with Crucini's indices they appear weakly procyclical.

Table II also shows the cyclical pattern in (gross) investment in capital for household production, that is, the flow of consumer durables. Shaw (1947) presents an annual series for this variable from 1889 through 1939. It is independent of both the prewar and interwar industrial production indices. Deviation from trend in durables consumption appears strongly procyclical before and after the First World War. Indeed, examination of the Shaw series shows that an absolute decline in household capital investment accompanied every downturn in the Gordon real GNP series, with two exceptions: 1919, the end of the First World War, and 1896, when durables consumption showed no growth over the previous year.

To summarize, the general patterns of business-cycle history appear to be the following. Prewar 
business cycles were larger than postwar cycles, in terms of deviation from trend output and employment, but not more frequent. They were associated with the same patterns in most real variables - consumption, investment (including household investment), and the trade balance - that appear in postwar cycles. The interwar Great Depression was an extreme case of standard patterns. On the other hand, there are obvious differences between prewar and postwar periods in the cyclical behavior of nominal variables. Described in terms of a conventional Phillips curve, the coefficient on past inflation was larger in the postwar period than in the prewar period, though the coefficient on output deviation was more or less the same. Some of the disagreement among macroeconomists over the historical stability of the Phillips curve can be resolved by noting that changes in the inflation process altered the relationship between innovations in inflation and output.

\section{CONFRONTING THEORY WITH HISTORY}

These patterns and other research in economic history bear on many issues in business-cycle theory. Here we focus on the debate between the two major schools of thought in macroeconomics at present: the "new classical" or "real" business cycle approach versus the Keynesian approach and modern "new Keynesian" attempts to fill in the holes in the old Keynesian model. We judge the plausibility of each school's models in light of historical experience. Along the way we point out some important open questions for empirical study.

\section{New Classical (Real Business Cycle) Models \\ What Causes Business Cycles?}

New classical models assume that cyclical-frequency variations in output and employment are caused by shocks to real preferences and constraints: "no matter how monetary policy is conducted, the behavior of real quantities is determined by real shocks to the economy" (Manuelli, 1986). Such shocks might include temporary changes in the government's demand for goods and services (as in Barro, 1981, 
Christiano and Eichenbaum, 1992) or changes in the expected return to saving and investment. However, assuming conventional household utility functions, either of these would cause consumption to move in the opposite direction from output and employment. ${ }^{5}$ Since consumption appears decidedly procyclical in all historical periods, new classical models must rely on another sort of real shock: procyclical fluctuations in the return to "employment" versus "leisure" (Barro and King, 1984, Mankiw, 1989). If wages reflect the return to employment and the return to "leisure" is fixed, then the models imply that real consumption wages must be procyclical. The failure of most empirical studies to find such a pattern has been taken as evidence against new classical models (David Romer, 1993). Barro and King (1984) speculate that real wages need not reflect the return to employment if employment relations are long-term and firms smooth real wages to insure employees against cyclical shocks. A study of real consumption wages in the prewar period might be useful here. Before the First World War most workers' attachments to firms were not long term: turnover was much higher, employment spells much shorter, and a laid-off worker much less likely to be rehired by his old firm than in later decades (Jacoby, 1985, Jacoby and Sharma, 1992). Prewar data on wage rates and prices of consumption goods ought to show the underlying pattern in the return to employment even if postwar data do not.

What might be the exogenous source of short-run fluctuations in the return to employment? Procyclical variations in the rate at which domestic output can be exchanged for foreign goods would do the trick (Mendoza, 1991). But they would presumably appear as a procyclical pattern in the terms of trade and the trade balance. As noted above, there is no strong procyclical pattern in the terms of trade in any historical period, and the trade balance appears countercyclical in all periods.

\section{Exogenous Shocks to Technology}

That leaves cyclical-frequency shocks to technology - that is, physical factor productivity - as the fundamental cause of business cycles under new classical assumptions. To account for the absolute decreases in output and employment that occur in cyclical downturns, models that assume a fixed utility value of "leisure" (as in Plosser, 1989) require absolute deteriorations of total factor productivity. Models 
that assume "leisure" includes home production as well as true leisure, and that the technology of the home sector, like that of the market sector, is subject to rapid changes, do not require such absolute deteriorations: improvements in home technology relative to market technology can cause a reallocation of time to home production, reducing market-sector employment and output (Benhabib, Rogerson, and Wright, 1991). The latter class of new classical model appears implausible if only because, as noted above, investment in household capital (consumer durables) is and always has been procyclical, just like investment in capital for market production. Household investment is negatively correlated with time allocated to household production. The hypothesized improvements in home technology would have to be associated with decreases in investment in the associated capital stock, the opposite of the relation observed in the market sector.

In any case, new classical models require exogenous shocks to economy-wide factor productivity to explain the patterns in consumption, investment, and the trade balance that appear in all historical periods. The shocks must be fast enough to create cyclical frequencies and large enough to account for cyclical amplitudes. At least for the postwar period that seems to mean movements from one year to the next on the order of two or three per cent of total GDP (see, for example, Plosser 1989).

Aggregate total factor productivity is determined by the productivity of individual producers, firms or households. Changes in aggregate productivity reflect changes in the technologies applied by those producers, as existing firms (households) apply new technologies, or old firms (households) are replaced by new ones utilizing new techniques. The behavior over time of aggregate total factor productivity is determined by the process generating technological innovations, the speed with which innovations are implemented by producers, the magnitude of the savings in input requirements associated with each innovation, and the importance in total final output of the sector or sectors utilizing that innovation.

New classical business-cycle theory thus rests on a hypothesis about technological innovation and diffusion. Individual innovations must be large and rapidly diffused to create significant quarter-to-quarter variations in aggregate productivity. Many small innovations diffused slowly could not deliver the 
magnitude of sudden shocks required by new classical models unless they came in bunches, for reasons exogenous to aggregate demand or the expected return on investment.

\section{Technology Shocks in History}

One can test the new classical hypothesis about technological change against the considerable body of research on technological innovation and diffusion, much of which has taken place within the context of economic history. One aspect of the "cliometric revolution" was the careful dating and quantification of observations about technological changes, including estimates of their effects on total factor productivity. Economic history is also useful here because long hindsight allows one to identify the innovations that might be big enough to make a difference in the aggregate and hence provide appropriate tests of the new classical hypothesis.

Three innovations that have attracted the attention of economic historians, precisely because they appear so overwhelmingly important, are steam-powered railroads, stationary steam engines (to power machinery), and electric motors. Railroads were introduced to the United States in the 1830s, with more than two thousand miles of way in operation by 1840 (U.S. Bureau of the Census 1975, series Q321). Robert Fogel (1964) and Albert Fishlow (1965) described the effect of railroads on total factor productivity in terms of "social savings." They compared aggregate output in certain years to estimates of what annual output would have been in the absence of railroads using the next-best transportation technologies and the same stocks of land, labor and capital. Fogel guessed that railroad freight service alone had increased total factor productivity by four to five per cent as of 1890 . Fishlow estimated that both freight and passenger service had increased factor productivity by five per cent as of 1859 . Either estimate implies that railroads increased total factor productivity by a negligible amount from one year to the next, for no single year saw a significant fraction of the rail network put in place, and there were gradual improvements in railroad technology all along.

G.N. von Tunzelmann (1978) presents an estimate along these lines for the effect of the steam engine on British GNP growth in the early nineteenth century: 
For Boulton and Watt engines alone (including their pirates) the social savings over atmospheric engines can be put at about 0.11 per cent of national income in 1800 . If total real output was then growing at its average rate for the take-off years, the level of national income reached on 1 January 1801 would not have been attained much before 1 February 1801 without James Watt. If all steam engines, Watt and atmospheric alike, were hypothetically replaced with other means of motive power (a combination of water and wind would be optimal), the setback would have been about two months. These are upward-biassed figures. (p. 286)

There is no similar estimate for the effect of steam engines on American GNP growth, but it could scarcely have been greater. Steam engines replaced waterpower at a very gradual rate. It was not until the 1860s that steam produced more horsepower (Atack, Bateman, and Weiss, 1980, p. 282).

The subsequent replacement of steam engines by electric motors was also slow. "Steam power prevailed at the turn of the century..By 1920 , electricity had replaced steam as the major source of motive power, and in 1929 - just 45 years after their first use in a factory - electric motors represented about 78 per cent of total capacity for driving machinery" (Devine, 1983, p. 349). Paul David (1990) guesses that the adoption of the electric motor accounts for "approximately half of the 5 percentage point acceleration recorded in the aggregate TFP growth rate of the U.S. manufacturing sector during 1919-29 (compared with 1909-19)" (p. 359). That does not translate into much of an effect on total factor productivity within a period relevant for business cycles.

The rates of diffusion for these particularly important technological innovations were not especially slow. Edwin Mansfield's (1961) study of interwar and postwar innovations found that "the diffusion of a new technique is generally a rather slow process. Measuring from the date of the first successful commercial application, it took 20 years or more for all the major firms to install centralized traffic control, car retarders, by-product coal ovens, and continuous annealing. Only in the case of the pallet-loading machine, tin container, and continuous mining machine did it take 10 years or less for all the major firms to install them" (p. 744). "The empirical picture is clear. Research from a wide variety of disciplines has shown that new technologies are not diffused instantaneously into the prevailing economic and social structure and that the pattern of diffusion can vary greatly across technologies and industries, in some cases being drawn out over decades" (Metcalfe, 1990, p. 17). Salter (1960, pp. 95-99) reviewed the 
history of the diffusion of new technologies in many industries, in the United States and United Kingdom, for the nineteenth and twentieth centuries. He argued that the slow diffusion of technological change is largely attributable to the physical embodiment of technological change in fixed capital, and the slow replacement of fixed capital in response to new technologies. Salter showed that embodied changes in technology that cut costs in half often coexisted with older technologies embodied in earlier vintages of capital. The adjustment of the capital stock, in some cases, is measured in decades. Average-practice techniques often deviate significantly from best-practice.

We conclude that the diffusion of any one technological innovation could not increase aggregate factor productivity by more than a trivial amount from one year to the next. If no single innovation can make much of a difference, it seems extremely unlikely that the aggregate rate of improvement could vary exogenously over cyclical frequencies to an important degree.

What, then, explains procyclical labor productivity, which is strongly apparent in aggregate and industry-level data in both the interwar and postwar periods? Before the advent of new classical macroeconomics, the standard explanation of this phenomenon was that measured employment does not exactly correspond to labor input. Firms "hoard labor" when output is low because it is cheaper to keep idle workers on hand than to fire them and hire new ones when product demand picks up. Robert Solow (1968) presents a model of this phenomenon. Another explanation is that some employment is a fixed input, "overhead labor"; "the aggregate hours worked by some kinds of employees counted as 'production and related workers,' e.g., watchmen, are not likely to increase or decrease as fast as production" (Hultgren, 1960, p. 27). ${ }^{6}$

Historical evidence is quite consistent with these old-fashioned explanations. Bernanke and Parkinson (1991) point out that if one takes the postwar pattern as evidence in favor of productivity shocks, the very similar pattern over the interwar period must be evidence that "changes in industrial technologies caused the Depression" (p. 457). "No one, including the real business cycle school, seriously maintains that the great Depression was caused primarily by technological shocks to industry production 
functions" (p. 448). Along the same lines, Mankiw (1989) notes that: "The increase in output associated with the World War II buildup is most plausibly a demand-driven phenomenon. Yet from 1939 to 1944 measured total factor productivity grew an average of 7.6 per cent per year. (By contrast, the most productivity has grown in any year since then is 5.2 per cent in 1950)" (p. 85). We mentioned the possibility that labor productivity was not procyclical in the prewar period, based on evidence for the depression of the 1890s (Weir, 1986, Carter and Sutch, 1990). This evidence runs counter to the newclassical premise that technology shocks caused cyclical variation, especially if one can argue that overhead labor and labor hoarding were less important before the First World War than in later periods. Solid evidence of a general pattern of acyclical productivity during this period has yet to be produced.

So far we have not discussed the phenomenon of technological regress, which most new classical models rely on to explain cyclical downturns. Technological regress does not appear to correspond to any event in Western economic history since the fall of the Roman Empire. Two proponents of the new classical approach, Gary Hansen and Edward Prescott (1993), recently admitted as much. "Although the rate at which inventions and discoveries are made may vary over time, the stock of knowledge should not decrease. Thus, these variations are not likely to account for the negative growth rates sometimes observed." Hansen and Prescott suggest that "changes in the legal and regulatory system within a country often induce negative as well as positive changes in technology" (p. 281). The effect of institutions on economic performance is an important focus of economic history (see for example North 1990). The burst of growth in West Germany after the monetary reform of 1948 was as large and rapid as a cyclical recovery. But one would be hard-pressed to identify such events in American history, and certainly one could not imagine a string of such events to account for experienced downturns and upturns.

An emphasis on changes in regulatory policy, fiscal policy, or institutional change as a source of "technology" shocks works against the real business cycle paradigm. Prior to World War I, when regulation, fiscal policy, and government institutions were far less prevalent (Hughes, 1991), and when changes in such policies were relatively infrequent, business cycle were more pronounced. The post- 
World War II era has seen dramatic increases in government activism, and a much greater frequency of change in fiscal and regulatory policies, while business cycles dampened.

Output Variations as a Cause of Technological Change

While it is impossible to argue that exogenous changes in the rate of aggregate productivity growth cause business cycles, there is plenty of evidence for an effect the other way around: cyclical-frequency variations in output and employment affect the rate of technological innovation and diffusion, and the average productivity of operating firms. Demand-driven business cycles can have long-run effects on the economy through aggregate factor productivity as well as investment.

Mansfield (1983) examines the correlation between technological innovation (measured by the patent rate) and cyclical variation in capacity utilization. He finds evidence of a positive correlation between the two, but that at high rates of capacity utilization the correlation turns negative. Sokoloff (1988) and Khan and Sokoloff (1993) provide much stronger evidence of the procyclicality of patenting for the antebellum period.

Paul David (1975) studies several examples of demand-induced technological change. He argues that permanent productivity improvements came from endogenous technological innovation and diffusion, and that these can be traced to economies of scale or learning effects. In the case of the cotton textile industry, early growth (due to the isolation produced by the Napoleonic Wars and subsequent tariff protection) made possible lasting technological improvements through learning. In the case of the reaper (which greatly reduced the cost of harvesting wheat), the temporarily high international demand for grain during the Crimean War promoted an expansion of farm acreage and encouraged the rapid diffusion of the new technology in the American middle west.

Bresnahan and Raff (1991) analyze technological change in the automobile industry during the Depression. They find that the collapse of demand forced the permanent closure of old-fashioned production plants, and thereby hastened the advance of technological change and increased average productivity during the recovery from the Depression. 
The notion that demand shocks can cause permanent increases in output is squarely at odds with many recent macroeconometric attempts to identify aggregate-demand and technology shocks (Blanchard and Quah, 1988, Shapiro and Watson, 1988). These studies assume that aggregate demand shocks are transitory, and/or that aggregate-demand shocks are uncorrelated with shifts in aggregate supply, and conclude that aggregate-demand shocks explain little cyclical variation. But it may be that much of cyclical-frequency variation in output is produced by demand shocks that induce long-run changes in productivity.

Technological change is only one of the mechanisms linking shifts in aggregate demand and supply. For example, Bernanke (1983) argues that bank failures and reductions in the net worth of banks and their borrowers, which resulted from the aggregate-demand shocks of 1929-1933, shifted aggregate supply by reducing the effectiveness of capital markets in linking ultimate suppliers of funds to worthwhile uses of funds (see also Bernanke and James, 1991, Calomiris, 1993, and Bernanke, 1994). Other examples of endogenous supply shifts produced by aggregate-demand disturbances can be found in the voluminous literature on "Kuznets cycles" (economic fluctuations associated with cycles of roughly 18-year average duration), which we discuss below. A consistent theme of that literature has been that persistent changes in supply related to immigration and capital flows may have been triggered by aggregate-demand fluctuations.

\section{Keynesian Models}

\section{What Causes Business Cycles?}

The "IS-LM" model following John Maynard Keynes (1936) and John R. Hicks (1937) is based on two assumptions: real money balances are substitutes for capital assets, and nominal wages, prices, and debt obligations under-adjust to aggregate shocks. At least in the short run - say from one month to the next - they are "sticky." Keynes, Hicks and most of their American followers believed that wage rates were the main source of nominal rigidities. Nominal price rigidities followed because prices were set as a 
mark-up over marginal cost. Since the 1970 s textbook Keynesian models have combined the IS-LM model with an "aggregate supply" function that allows for exogenous price shocks ("supply shocks") from agriculture and foreign trade and have allowed for nominal rigidities in product prices per se. A "new Keynesian" literature has attempted to derive the features of the old Keynesian model from standard utility functions and more "fundamental" constraints. Many new Keynesian models describe nominal rigidities in prices with no special reference to wage rates, or even an assumption that nominal wages adjust to clear labor markets. So far the similar puzzle of fixed nominal debt contracts, also an important part of the old Keynesian story, has attracted surprisingly little attention.

Purely monetary shocks, like changes in the aggregate money-demand function or changes in the rate of growth of the money supply, have no (or minimal) real effects in new classical models. In Keynesian models monetary shocks cause variations in employment and real output, procyclical movements in consumption and investment (both market and household), and countercyclical movements in the trade balance. Monetary shocks affect real variables in three ways that operate together but are theoretically distinct.

First, the production level chosen by a profit-maximizing firm varies when the nominal product demand schedule shifts relative to sticky prices of products or factors. When demand falls, for example, a firm that is constrained from cutting the nominal wage rates it pays for given jobs will lay off employees, though the workers' marginal revenue product remains greater than the value of their best alternative opportunity: low-value "underemployment," a search for another job, even involuntary unemployment.

Second, whether or not wages and prices are sticky, changes in demand affect the size of existing nominal debt obligations relative to debtors' nominal incomes. In the presence of some plausible capital-market imperfections the real burden of existing debt affects investment and consumption as described by Ben Bernanke (1983). Keynes himself was confused on this point, arguing that a fall in aggregate demand would increase debt burdens only if it were associated with a fall in wages and prices (1936, p. 264). In fact, the real burden of a fixed nominal debt depends on the size of the contracted 
payments relative to the debtor's nominal income or wealth. Real income and wealth fall with aggregate demand even if wages and prices are rigid.

Third, since wages and prices are not absolutely rigid, changes in nominal aggregate demand should be associated with changes in expected inflation rates. Changes in expected inflation affect the expected real return to holding money balances and the demand for real assets. This implies that during the wage and price adjustment process, a higher expected inflation rate will offset somewhat the expansionary effect of a temporary increase in real balances produced by sticky prices. DeLong and Summers (1986) show that for some price- and wage-setting rules this effect even can make business cycle volatility an increasing function of the degree of price flexibility because greater price flexibility increases the rate of expected inflation during the adjustment process.

In Keynesian models, aggregate real shocks like changes in government spending or changes in the expected return to investment have effects quite different from those predicted by new classical models. As Keynesian "IS" shocks, all can be associated with procyclical movements in consumption and investment and countercyclical movements in the trade balance. Also unlike new classical models, Keynesian models have no necessary implication for the real return to employment. Real wages may be countercyclical, acyclical or procyclical depending on the relative rigidity of prices versus wages (Barro, 1979, p. 59, Mankiw, 1990, p. 1657). Real wages could be procyclical even if firms were free to choose prices subject to sticky nominal wage rates, as long as profit-maximizing price mark-ups over marginal cost were countercyclical (Dunlop, 1938, Keynes, 1939, Tobin, 1993). Countercyclical mark-ups can be derived from a number of different assumptions about the structure of product markets (for examples, see Bils, 1989, Rotemberg and Woodford, 1991).

\section{Keynesian Models and Business Cycles Before the Second World War}

The predictions of Keynesian models are consistent with the cyclical patterns in real variables that appear in the prewar and interwar periods as well as the postwar period. Perhaps more importantly, they 
point to specific causes of most business cycles in terms of observable events. Narratives like those of Friedman and Schwartz (1963) and Rendigs Fels (1959) present a long catalogue of plausible monetary ("LM") and spending ("IS") shocks to account for almost every upturn and downturn as defined by the NBER - an embarrassment of riches that has only been carefully studied for the case of the interwar Great Depression (for example Temin, 1989).

The macroeconomic events of 1929-1941 pose no special problems for Keynesian theory, unlike new classical theories. As Robert Barro (1979) has noted: "From a reduced-form perspective that relates business fluctuations to prior monetary disturbances, the contraction from 1930 to 1933 seems well in line with other experiences. The unprecedented monetary collapse over this period accords quantitatively with the drastic decline in economic activity" (p. 58). Christina Romer (1993) argues that "the path of output and employment in the United States in the 1930 s is, contrary to common perception, very well understood" (p. 24) in terms of a standard Keynesian model.

The United States slipped into recession in mid-1929 because of tight domestic monetary policy aimed at stemming speculation on the U.S. stock market. The Great Depression started in earnest when the stock market crash in the United States caused consumers and firms to become nervous and therefore to stop buying irreversible durable goods. The American Depression worsened when banking panics swept undiversified and overextended rural banks and the Federal Reserve failed to intervene. Finally, the American Depression ended when the Roosevelt administration chose to increase the money supply tremendously after 1933 (p. 37).

The increase in the money supply "had exactly the effect on the U.S. economy that a traditional aggregate supply-aggregate demand model would lead one to predict...real interest rates plummeted in response to the gold inflows...followed fairly quickly by a recovery of interest-sensitive spending, such as construction spending and consumer purchases of durable goods" (p. 36). While Romer's description of the Great Depression may attach too little weight to long-lived disruptions ("supply-side" shifts) that followed the severe aggregate-demand 'shocks of 1929-1933, she is on firm ground in her claim that the downturns and upturns of 1929-1941 are associated with the movements in monetary variables predicted by the Keynesian model. 
Nominal Wage Rigidity in History

No one who makes payments on a mortgage or student loan would quarrel with the assumption that some intertemporal contracts fix payments in nominal terms. It is no less clear that some product prices are held fixed for months at a time even in cyclical downturns, as was noted before the Second World War (Means, 1935) and has been amply documented in the postwar period (for example, Carlton, 1986). Under-adjustment of nominal wage rates is harder to discern, especially in an inflationary environment. In the postwar period the upward trend in real wages together with the absence of absolute decreases in prices and nominal aggregate demand even in downturns means that nominal wage rates for most jobs are increased every year. Adjusting a wage rate to an economy-wide shock or relative to other wages is a matter of a larger or smaller increase. There are also problems of constructing consistent data to measure wages. Over most of the postwar period no agency collected comprehensive time-series data on wage rates. The best proxies have been series on average hourly earnings. These are affected by cyclical patterns in the composition of employment among low- and high-wage sectors, firms within a sector, and workers within a firm (U.S. Bureau of Labor Statistics, 1969). Average hourly earnings series could vary considerably over a business cycle even if all nominal wage rates were held fixed.

The nature of wage and price adjustment might be easier to observe in data from earlier periods. Average nominal wage rates rose very little over the late 1920s (U.S. Bureau of the Census 1975, series D802) and from the 1870 s through the late 1890 s (see Long, 1960, p. 67, Rees, 1961, p. 38). Most importantly, before the Second World War most cyclical downturns saw absolute declines in the money supply and prices with relatively little change in wages. This was certainly true in the depressions of 1893, 1907, and 1929. In all three downturns the money supply, wholesale prices, and consumer prices fell along with industrial production, real GNP and employment (according to anyone's series). ${ }^{7}$

Fortunately, each of these depressions left behind records of changes in wage rates paid by firms for given jobs which are quite consistent with the notion that wage rigidity was associated with significant layoffs during business cycle downturns in the face of falling aggregate demand and falling prices. The 
NBER dates the 1893 depression as a peak in January 1893 and a trough in June 1894. In 1894 the state labor bureaus of New York, Ohio, Connecticut and Maine surveyed establishments as to whether they had cut wage rates over the calendar year 1893 or in a period from early 1893 through summer 1894 . The Ohio bureau continued its surveys through the 1900 s, covering the NBER peak in May 1907 and trough in June 1908. These state surveys are described by William Sundstrom (1990, 1992), Carter and Sutch (1990), and Hanes (1993). In every survey, many establishments reported cuts in wage rates for some or all occupations. This is consistent with available time-series on average wage rates or hourly earnings, which show decreases over the same years. But in all but one survey, most establishments reported they had not cut wage rates for any occupation, even though they had cut employment by large percentages. (The Ohio 1894 survey did not ask about employment, but other data show that employment fell a lot in the same sectors and geographic area [Sundstrom, 1990].) The exception is the Connecticut 1894 survey, which includes the longest period after the downturn (through August 1894). In that survey slightly more than half of the establishments reported wage cuts (Carter and Sutch, 1990, p. 17). In the early 1930s the U.S. Bureau of Labor Statistics collected similar (but not directly comparable) information on wage rate changes. These data show that many establishments held wage rates fixed until more than a year after the downturn from the NBER peak in August 1929, long after they had cut employment (Shister, 1944, Mitchell, 1985).

There is no way to be sure that the behavior of the firms in these samples was representative of firms in general, but the surveys' results are certainly consistent with other information about firms' wage rate changes in these downturns. Robert Ozanne's (1968) study of International Harvester, originally the McCormick Reaper Company, shows that the firm cut employment early in each of the three depressions. But in 1893 the company "cut only the [wages of] skilled workers and those on piece rates. Eventually, three years after the depression began, the McCormick firm cut [wages for] common labor 1 cent" (Ozanne, p. 32). After the 1907 downturn International Harvester did not cut wages until the beginning of 1908 (p. 37). After 1929 "the company took no action to cut wages...Finally, in October, 1931, the first 
production worker wage cuts of 15 per cent were instituted" (p. 52). In 1908 U.S. Steel and other large steel producers refrained from wage cuts despite deep reductions in employment (Shergold, 1975, p. 181). After 1929 U.S. Steel held its common labor wage fixed until October 1931. Other firms appear to have followed the same policy. "If we believe the newspapers, magazines, trade publications, and academic journals of the time, money wages in manufacturing were not cut until the fall of 1931" (O'Brien, 1989, p. 720, 721, see also Jacoby, 1985, pp. 216,217 ). There can be no reasonable doubt that in each of these depressions, months after wholesale and consumer prices had begun to fall, establishments accounting for a significant fraction of aggregate employment and output held their nominal wages absolutely fixed as they cut production and laid off workers. ${ }^{8}$

Note that all of this evidence is in regard to wages in just one sector - manufacturing. It is important to note that nominal wage rigidity in the manufacturing sector need not have had the same effects on aggregate output and employment in the prewar and interwar periods as in the postwar period. As we have already mentioned, agriculture is an acyclical sector, and it was much more important before the Second World War. Unlike manufacturing wages, farm wages appear to have adjusted quickly to aggregate shocks (Goldin and Margo, 1992), and at least in the nineteenth century, workers moved between the manufacturing and farm sectors at seasonal and cyclical frequencies (Dawley, 1976, Keyssar, 1986, Goldin and Engerman, 1993).

The decline in the intersectoral substitution of labor is also related to the decline in labor turnover within manufacturing over time. Margo (1990a, 1990b, 1991) shows that the duration of unemployment spells in the manufacturing sector was relatively short prior to the Great Depression, and that longduration unemployment became much more common during and after the 1930s. Some of the high historical turnover rate (short unemployment spell duration) in manufacturing likely reflected substitution into agriculture during cyclical and seasonal lulls in manufacturing. 9 The elasticity of labor substitution across sectors, and the turnover of labor, was reduced in the early twentieth century (Jacoby and Sharma, 1992). 
The relative ease with which labor moved across sectors before the First World War, combined with the smaller size of the manufacturing sector relative to farming, the acyclicality of agricultural production, and the more rapid adjustment of nominal wages in agriculture than manufacturing all made it easier for displaced manufacturing workers to be absorbed in agriculture. Thus, a cyclical downturn in manufacturing and other sticky-wage sectors could have pushed workers into agricultural underemployment rather than unemployment.

\section{Wage Rigidity and the Phillips Curve}

In our discussion of wage rigidity, we have so far avoided reference to results of the Phillips curves studies referred to earlier. That is because none of those studies makes much effort to relate the coefficients of estimated relations to an underlying model of the system of setting prices, wages, and output. Under any reasonable assumptions, the estimated relations are at best reduced forms of much more complex systems, and interpretation of estimated coefficients is not straightforward. Hanes (1994) shows that changes in estimated Phillips curve coefficients can reflect changes in the volatility of shocks to aggregate demand as well as changes in wage and price setting behavior.

Moreover, as discussed above and as noted by Alogoskoufis and Smith (1991), Calomiris (1993a), Obstfeld (1993), and Hanes (1994), changes in the persistence of forcing processes to which wages are responding (like monetary growth and inflation) can affect the correlations between price and output change, and therefore affect the interpretation of correlations between price and output processes.

Finally, factors other than wage and price rigidity can account for correlations between nominal price change and real output or employment. Calomiris and Hubbard (1989), in their study of monthly data for the period 1894-1909, argue that the Phillips curve does not necessarily reflect the lack of market clearing in labor or product markets or measure the degree of price and wage rigidity. Instead, aggregate output-price correlations may reflect the contractionary effects of aggregate-demand shocks operating through debt deflation. Calomiris and Hubbard (1989) find that much of the co-movement between the wholesale price index and output over the business cycle reflects changes that originate as price 
innovations. Such innovations could have real effects either due to rigid nominal wages or through predetermined financial contracts (debt deflation). The relative weights of wage rigidity, debt deflation, and other factors in explaining wage, price, and output correlations in manufacturing remains an open issue for future research.

\section{History and New Keynesian Models}

\section{Menu Costs}

The most general explanation of nominal wage and price rigidity offered by New Keynesian models is the notion of "menu costs." Menu cost models show that a firm's incentive to adjust prices to shifts in nominal aggregate demand can be small if its product market is less than perfectly competitive (Mankiw, 1985). As Robert Gordon (1990) and David Romer (1993) point out, the menu-cost argument also applies to wages, whether they are set by firms or monopoly unions. The less elastic is product demand, the smaller the increase in profit resulting from a decrease in marginal cost and hence the smaller the firm's incentive to cut wages. The firm's derived demand for labor is also less elastic, so allowing a wage cut gives workers a relatively small increase in employment (a small decrease in the probability of being laid off).

If the benefit of adjusting prices or wages is small, a small "menu" cost of adjustment itself is enough to cause the setter to hold them fixed. It is not clear, however, what these menu costs might be. So far proponents of these models have invoked various forms of transactions and administrative costs.

"Taken literally, these menu costs are the resources required to post new price lists. More metaphorically, these menu costs include the time taken to inform customers, the customer annoyance caused by price changes, and the effort required even to think about a price change" (Mankiw, 1990, p. 1657). But failing to adjust prices brings on administrative costs of adjusting output and employment - costs of cutting production, laying off workers (with the associated turnover costs), closing down plants altogether - which seem larger, if anything. 
What kind of costs could apply to wage and price changes alone? The Great Depression offers an example: public disapproval, government pressure and regulations. Anthony O'Brien (1989) argues that in the 1920 s it was generally believed that wage and price deflation made depressions worse, or even caused them. "By the mid-1920s many manufacturing firms had publicly announced that wages rates would not be reduced during the next downturn" (p. 724). Shortly after the stock-market crash President Hoover called a conference of large employers to encourage them to maintain nominal wage rates. Most promised to do so. Thus "cutting wage rates at the onset of the depression" would have been a "public relations debacle" (p. 729). In 1933 the National Industrial Recovery Act created minimum wages and other forms of regulation that raised nominal wages and prices after deflation had set in and before any considerable upturn in employment. Michael Weinstein (1981) points out that "the economy could not have recovered in historically expected ways as long as the NIRA wage and price regulations were effective" (p. 279).

These policies were peculiar to the 1930 s, of course, but it may be useful to consider the reasons that rational government and business administrators came to adopt such policies, and whether they have general implications. Olmstead and Rhode (1985) argue that similar "social pressures" were important in restricting gasoline price increases during the California gasoline famine of 1920 . Gasoline sellers voluntarily chose to ration fuel rather than increase its price to the market clearing level, which Olmstead and Rhode argue reflected their fears of violent public reactions to price increases.

\section{Long-Term Contracts}

As mentioned above, old Keynesian models assumed that the price of labor is the most important source of nominal "stickiness" in the economic system, and that firms chose employment levels to equalize the marginal revenue product of labor to the sticky marginal cost of labor implied by wage rates. Marginal labor costs would include other costs contingent on the number of workers employed, like pension contributions and health insurance. Such costs were negligible before the Second World War.

The old Keynesian view of wages and employment appeared to be undermined by early work in the microeconomic theory of optimal contracts (following Azariadis, 1975). If firms were bound to 
workers in some kind of long-term relationship, employment and earnings might follow the terms of an explicit or implicit state-contingent contract that set employment at the optimal level, where the marginal revenue product of labor equalled its opportunity cost, and stipulated payments to workers so as to equalize the marginal utility of income across states. Under such an agreement the nominal or real "wage rate" prevailing at any point in time would be nothing more than the state-contingent payment divided by the state-contingent quantity of labor supplied. It would not be a price in the ordinary sense, and would have no direct relation to employment (Barro and King, 1984).

This argument seems to have been accepted by some new Keynesians, contributing to the recent emphasis on price rather than wage rigidity, though it applies just as well to product prices: firms can also have long-term relationships with suppliers of raw materials and with consumers of final products.

Fortunately, later work following Calvo and Phelps (1977) showed that the neutrality argument depends on an implausible assumption that workers know as much as firms about the value of labor's product. If a firm has private information and is willing to trade off some amount of expected profit for a reduction in its variance - a consequence of the same financial-market imperfections that generate real effects of a debt burden - then the optimal contract leaves the firm free to choose the employment level subject to positive marginal costs of labor (Azariadis and Stiglitz, 1983), just as in the old Keynesian story. Thus, the problem becomes one of accounting for the under-adjustment of marginal labor costs, that is, wage rates (and employment-contingent benefits), to aggregate shocks.

Many Keynesian models of the late 1970 s accounted for the under-adjustment of nominal wage rates with an assumption that wages were set by long-term contracts before the realization of aggregate shocks. This was often justified as a depiction of American union labor contracts, which set nominal wage rates for one to three years with little or no indexing. The relation between union contracts and nominal wage rigidity seemed to be confirmed by the earliest studies of wage and price behavior based on standard historical series for output, prices and average hourly earnings. As we mentioned above, Cagan (1975) and Sachs (1980) showed a decrease in Phillips-curve coefficients on output and lagged inflation from 
prewar or interwar periods to the postwar period. That matched up nicely to the timing of the spread of unions and long-term wage contracts across the manufacturing sector. Robert Gordon (1986) summarized the conventional wisdom:

The greater postwar persistence of wages and prices is generally attributed to two factors. First, the increased importance of labor unions since the late 1930s has led to centralized wage bargaining, and high perceived costs of negotiation have made it economical to establish three-year contracts in many industries. That today's wage changes were in many cases agreed upon last year or the year before tends to insulate wage changes from current market forces and to increase their dependence on what has happened previously. Second, the greater confidence of private agents in the willingness of monetary and fiscal policy to reduce the severity of recessions lessens their need to reduce wages and prices quickly and increases their incentive to wait for the expected prompt return of prosperity. (p. 20).

But pointing to union contracts or any other long-term price arrangements did not amount to an explanation of nominal rigidity. Why should workers and firms fail to adjust the marginal cost of labor, determined by the terms of the contract, to aggregate shocks that both sides should be able to observe? Wage bargainers should adjust rates set by a long-term contract to those shocks, either by renegotiating the contract or indexing its terms in advance. As Robert Barro put it, "long-term labor agreements do not imply a failure of employment to increase when all parties to the agreements perceive that they could be made better off by such a change" $(1979$, p. 54). Perfect indexation of a long-term contract may be impossible, if only because published price indices are very noisy measures of true changes in the price level (Meltzer, 1994; Bullard, 1994). But it is hard to account for a total lack of indexation in a three-year contract, or a failure to renegotiate a contract in the face of a general recession.

More importantly, wage rates display nominal rigidity in the absence of any kind of long-term contract. The historical association between union contracts and wage rigidity has not held up to further scrutiny. Recall that better wage and price series used in more recent studies of the Phillips curve show no decrease in the Phillips-curve coefficient on output (Allen, 1992, Hanes, 1993). The coefficient on lagged inflation still appears larger in the postwar period, but as we have argued, that did not reflect a change in the association between wages or prices and deviations of output from trend. Most importantly, the microeconomic historical evidence we have discussed indicates that many firms refrained from cutting wages in prewar and interwar depressions like 1893, 1907 and 1929 though few faced formal unions and 
none was constrained by a contract. Before the 1930 s courts did not enforce wage contracts between firms and worker groups even if they were written down.

\section{Insider-Outsider Models}

The lack of a historical correlation between formal contracts and nominal wage or price rigidity poses less of a problem for "insider-outsider" models like those described by Assar Lindbeck and Dennis Snower (1988). These have always emphasized that one source of union workers' bargaining power, the employer's costs of replacing its incumbent workforce, is present in nonunion firms as well. An informal group of workers (or even an individual worker) might be able to threaten a withdrawal of effort or "cooperation" and force the firm to pay wages greater than the value of alternative employment (or a search for alternative employment). Organization of a formal union might add to workers' bargaining power, but might be more a signal of bargaining power that had been there all along. If so, the fixed nominal wages set by union contracts may be an extreme version of a more general characteristic of wages set by bargaining.

Many patterns in postwar data are consistent with the ideas in the insider-outsider literature. Some nonunion firms appear to pay wage premia that resemble those in unionized firms - in excess of compensating differentials for unpleasant work conditions or differentials associated with an employee's human-capital characteristics, and paid to workers in virtually all the firm's jobs. High-wage firms are usually found in industries with certain characteristics: large establishments, firms with high capital-labor ratios, and firms that enjoy greater product market power (those with high profits and market shares). For example, wages are higher in manufacturing than in agriculture, and higher in machine tool manufacture than in textiles. Establishment size, capital-intensity and market-power indicators are highly correlated across sectors, so it is hard to identify which might bear a causal relation to wage premia (Dickens and Katz, 1987), but the latter two correlations are certainly "consistent with the idea that labor can extract rents which depend on how much damage it could do by temporarily stopping the firm from producing. Production interruptions are more costly for capital-intensive firms and those earning high profits than for 
other firms" (Katz and Summers, 1989, p. 241). Postwar data also suggest an association between high wages and nominal wage rigidity. Wage differentials across sectors and firms are countercyclical: wages in high-wage sectors fall less in recessions and rise less in booms (Wachter, 1970). But since firms in high-wage sectors are also more likely to be unionized, it is hard to say whether this pattern holds for high-wage nonunion firms.

Historical evidence allows one to separate the effects of workers' bargaining power and industry characteristics from those of formal unions and long-term contracts, since unions were rare before the late 1930s, even in manufacturing. Such evidence makes it clear that worker groups can threaten firms even in the absence of formal organization. In the late nineteenth century nonunion workers were capable of withdrawing effort in the most spectacular way, by going on strike (Hanes, 1993). Large-scale strikes by nonunion workers against cuts in nominal wages and threatened cuts continued through the 1920s (Wright, 1981), and it was observed that nonunion workers would slack off and damage machinery if they felt they had been treated "unfairly" (Mathewson, 1931). The firm characteristics that are associated with wage premia and unions in the postwar period were associated with strikes in the late nineteenth century (Hanes, 1993) and wage premia in the 1900s and 1920s, before the spread of unions (Krueger and Summers, 1987).

They were also associated with nominal wage rigidity. In the downturn after 1929 firms in industries with less competitive product markets and high capital-labor ratios were the last to cut wages (Shister, 1944). In the depression of 1893 firms were less likely to cut wages if their industries had suffered especially large numbers of strikes in earlier years (Hanes, 1993). Recall that the general historical pattern in the cyclical behavior of nominal wages and prices appears (at present) to be an increase in rigidity in the late nineteenth century, followed by no clear change to the postwar period. That would make sense if nominal rigidity were linked to the technologies and product-market structures associated with high wages, rather than with unionization per se. In America, firms with those characteristics came into being with the rise of mass production in the postbellum period. By most 
accounts, the 1870 s, 1880 s and 1890 s saw historically unique increases in establishment size, capital intensity and product-market concentration (Chandler, 1977, Spencer, 1977, Lamoreaux, 1985, Jacoby, 1985, O’Brien, 1988).

None of this is to suggest that current versions of insider-outsider models provide a theoretical explanation for nominal wage rigidity. Such models face exactly the same problem as models of formal long-term contracts: in either case, workers with bargaining power should adjust their wage demands to observable aggregate shocks. Insiders should not force the firm to pay wage rates that cause them to be laid off and become outsiders.

Efficiency Wages

The basic assumptions of most efficiency-wage models resemble those of insider-outsider models: a firm loses profit if its employees choose to reduce effort, or if it must replace incumbent workers (Stiglitz, 1986). But in efficiency-wage models the workers do not take strategic advantage of their ability to harm the firm: the workers do not make threats and bargain. The firm need only worry that employees will quit for non-strategic reasons, or will "shirk" to enjoy leisure on the job. Employees are less likely to quit or shirk if the firm's wage is higher than the value of workers' alternative employment, so a firm may choose to pay wage premia to reduce turnover and raise effort on the job. Sectors in which firms face especially large costs of turnover and monitoring will pay persistently high wages. The problems that would cause firms to pay efficiency wages should also cause firms to promise employees future rewards in the form of pensions, promotions and raises by seniority if they do not quit and are not caught slacking off on the job (Lazear, 1981). Such policies are generally referred to as "bureaucratic" or "internal labor market" employment patterns.

The phenomena described by efficiency-wage models have implications for nominal wage rigidity in that a firm's incentive to cut its wage when outside wages fall or unemployment rises is smaller if the cost of maintaining an unnecessarily high wage is partly offset by the benefit of lower turnover and less shirking. Thus, a small menu cost of changing wage rates could cause the firm to hold them fixed. 
In some ways, efficiency-wage models are a complement to insider-outsider models (Krueger and Summers, 1987). Efficiency-wage effects on the behavior of individual workers reduce the cost to the firm of giving in to a group's demands. In general, however, efficiency-wage and strategic-threat models are substitutes, offering alternative explanations of the same features of employment and wagesetting.

Historical evidence suggests that strategic threats and bargaining have been more important. Daniel Raff (1988) has examined Henry Ford's adoption of the "five dollar day" in 1914, a clear example of a policy to pay wages in excess of workers' alternative opportunities. "None of the three canonical efficiency wage theories - turnover costs, adverse selection, and moral hazard - speaks to a plausible central motive. A desire to buy the peace seems far more consistent with the facts. Ford was alone in his industry in paying such wages when he did because he was alone in his method of making automobiles" (p. 398). Ford faced "the specter of the sit-down strike. Ford's single-minded focus on a dedicated capital stock and economies of scale made the company peculiarly vulnerable. Its profits left the opportunity cost of such action to the owners of the company relatively high... The Wobblies had been in Detroit in the late springtime of 1913" (p. 396).

Sanford Jacoby (1985) describes the origins of the internal labor market policies that should be related to the payment of premium wages, if efficiency-wage models are correct. Jacoby finds that "the new bureaucratic approach to employment did not gradually take hold in an ever-growing number of firms" (p.8), as one might expect if it were a profit-maximizing managerial innovation. Instead, "the growth of internal labor markets in large firms was erratic, occurring chiefly during World War I and the Great Depression" (p. 280). At the same time firms came to see turnover as a bad thing, but: "The new concern with turnover was not attributable to any increase in separation costs associated with technological change of a firm-specific character. In fact, manufacturing technology was becoming less firm-specific and idiosyncratic than it had been in the nineteenth century" (p. 122).

The historical record indicates that the employment reforms introduced during World War I and after 1933 were attributable not so much to competitive market forces as to the growing power of the unions and the ascendance of the personnel department over other branches of management... With the benefit of forty years' hindsight, we may observe that these policies often enhanced efficiency by reducing turnover and 
increasing morale, or by stimulating programs to upgrade the work force. But this effect was by no means obvious to the managers of firms in transition, who were skeptical that internal labor market arrangements would lower costs. Efficiency incentives were neither strong enough nor obvious enough to produce the modern internal labor market (p. 277, 278).

Moreover, "personnel managers can be viewed as mere conduits for union threat effects in that many of their ideas were borrowed from the unions and their influence often rested on the imminence of labor unrest" (p. 281). The firms that adopted internal labor-market policies in the 1900s did so to "divert industry's skilled workers from the unions by means of quasi-pecuniary incentives, including profit-sharing, pension, and home ownership plans" (p. 52). When unions spread during the First World War: "Personnel management reduced the potential for unionization by replicating within the firm some of the union's protective structures" (p. 164). After unions were crushed in the early 1920 s personnel departments lost influence, but in the 1930s, after the NIRA and the Wagner Act: "The strategy of using employment reforms to deter unionism was given new life" (p. 242). Personnel managers cared about turnover because "the same conditions that gave rise to quits and low morale in the present might lead to strikes or worse in the future. If these conditions could be identified and remedied, they reasoned, morale would improve, quits would fall, and the possibility of industrial revolt would be greatly lessened" (p. 120).

\section{Historical Lessons for New Keynesians}

On the whole, historical experience suggests that nominal wage rigidity is associated with bilateral monopoly and bargaining between firms and groups of workers, whether or not the workers are organized in a formal union and the bargain takes the form of a formal contract.

The missing link between bargaining and nominal rigidity may perhaps be found in a set of ideas that has been more or less ignored in new Keynesian theory: agents' information about current levels of nominal demand may not be good enough to allow perfect adjustment of their behavior to monetary shocks. Lucas (1972) and Lucas and Woodford (1994) show the effects of such information problems in economies made up of pre-industrial producer-households. Gordon $(1981,1990)$ and Meltzer (1994) point out some reasons information can be imperfect in complex economies with many buyer-seller 
relationships, many commodities and long lags in the availability of reliable statistics on the aggregate price level. Such ignorance should affect the outcomes of bargaining between firms and groups of workers in negotiations of new long-term agreements or series of short-term agreements. "Insiders" may wish to adjust their wage demands to nominal shocks but lack the information to do so. The difficulty of indexing a long-term agreement to subsequent shocks is a related problem.

One need not assume that bargainers have no information about aggregate shocks; only that their information is less than perfect. In addition, the experience of the Great Depression suggests that violation of social norms may be a part of the cost of adjusting wages downward, and prices upward, in response to aggregate shocks.

\section{Rediscovering "Long Swings"}

A theme of business cycle research that is receiving increasing attention is that many disturbances to economic activity have long lives. The Great Depression is one prominent example, as is the "Eurosclerosis" of the 1980s. More generally, however, simple statistical decompositions that divide economic shocks into short-lived and long-lived disturbances find that a large proportion of variation in economic activity is attributable to long-lived shocks (Blanchard and Quah, 1988, Shapiro and Watson, 1988).

Persistent swings in output and employment pose an important challenge to explanations of business cycles that posit wage and price rigidities. Models of wage and price rigidity may have a difficult time explaining the persistence of economic disturbances, despite some attempts to do so (Blanchard and Summers, 1988). Clearly, menu cost models will not be capable of generating significant "long swings." But even models that posit institutional rigidities (as in insider-outsider stories) must face the following dilemma. Any contracting friction that creates significant unemployment of resources should also spur the development of competing producers to make use of those idle resources.

As we noted before, one way of explaining the persistence of high-frequency disturbances is to 
argue that demand shocks can have persistent effects, a common assumption in a wide variety of "endogenous-growth" models, and a point of view about the economy that goes back at least as far as Schumpeter (1939). In theory, endogenous persistence of "demand" shocks may be due to a variety of factors. One of the dangers of the "new growth" literature is that once one relaxes the simple neoclassical framework - with constant returns to scale and without externalities - it may be difficult to choose among the wealth of alternative possible explanations for endogenous persistence. An historical view of the economy, however, can help to give specific meaning to the notion of "long swings," and distinguish among various possible explanations for them.

It is worth noting that economic historians (and macroeconomists over the age of 50) have been thinking about endogenous growth for a long time. The notion that aggregate-demand disturbances have sometimes been associated with persistent growth or decline underlay a large literature on long swings, which largely went out of fashion by the late 1960 s.

The phenomenon of long-duration "Kuznets cycles" - of roughly 16-18 years - is central to American macroeconomic history. Indeed, anyone attempting to describe concisely the history of American economic development will find himself essentially plotting out Kuznets cycles. Kuznets cycles are not just a convenient means of organizing a long time series into clumps. Each cycle coincides with identifiable "eras" of fundamental change in the economy which are central to the "story" of how America developed. There is the era of canal building and canal bankruptcy, the period of rapid railroad building in the middle west during the 1850 s and the demise of the railroad boom prior to the Civil War, and the postbellum railroad booms and busts.

The Kuznets cycle literature did more than make notions of endogenous growth credible by identifying moments of persistent takeoff and collapse in the economy. It provided a descriptive body of evidence that can help macroeconomists choose from the number of plausible theoretical models which might explain long swings. Similar patterns of phenomena within each cycle suggest a common mechanism. The "phases" of the Kuznets cycle are remarkably common across the various cycles, and are 
associated with similar sequences of activities - most notably, the construction of transportation networks and structures, and massive waves of immigration. These similarities led proponents of the Kuznets cycle to describe long swings as "building cycles" (see Abramovitz, 1964, the review of this vast literature in Hughes, 1990, chapters 8 and 16, and Solomou, 1987, Zarnowitz, 1992).

There is widespread disagreement about how such cycles began - with possible triggers ranging from immigration shocks to financial or political factors that set the stage for expansion. ${ }^{10}$ There is similar disagreement about the factors that brought such cycles to an end. ${ }^{11}$ Whatever the answers to those questions, it is clear that land settlement, canal building, and railroad speculation on the frontier were central to the booms of the nineteenth century, and reversals in these processes were associated with rapid declines in migration westward and investment. For example, migration westward in April of 1857 resulted in the arrival of 1,000 people per day into Kansas alone. Railroads - which were speculating heavily in land, and building new lines in anticipation of a transcontinental trunk line - encouraged the migration by lowering the cost of passage by as much as 25 percent. Land prices soared, mortgage lending grew, and speculative railroad stocks boomed. Adverse political news in the middle of 1857 (associated with the conflict over slavery in the territories, and its consequences for timely construction of a transcontinental line) seems to have been responsible for a collapse of speculative land and railroad securities prices, and the end of rapid immigration (Calomiris and Schweikart, 1991). This experience illustrates the importance of expectations for migration decisions and land and railroad construction, and the potential for bootstrapping effects (mutually reinforcing expectations and investments). As Brinley Thomas (1954) notes, supply-side and demand-side forces often reinforced each other in producing economic growth, as international and interregional migration responded to differences in standards of living across locations. Analysis of the timing and location of persistent bursts of economic growth also show that long swings were closely tied to specific locations in which economic development was occurring very rapidly.

The common spatial patterns of long-run cycles historically in the United States suggest that a 
model of endogenous growth capable of explaining the Kuznets cycles must begin with a spatial conceptual framework for modeling economic activity (e.g., Murphy, Shleifer, and Vishny, 1989, Krugman, 1991). Waves of American economic development were associated with three related spatial phenomena - the settlement of an expanding frontier, the establishment of a transportation and communication network within the boundaries of that frontier, and the creation of high concentrations of population and economic activity which served as nodes within that network. Epochs of great expansion were times when large investments in transportation and communication occurred, removing pre-existing barriers to the flow of capital and labor, and allowing the reorganization of the production and distribution process within the economy (Chandler, 1977). These investments promoted massive flows of capital and labor, which chose to move to new locations, and often to concentrate in large cities.

This spatial interpretation of the Kuznets cycle suggests four related features of the spatial economy that seem essential to explaining moments of sudden change followed by persistent expansion or contraction. First, the decision to bear fixed costs is central to the suddenness of economic expansion that characterizes Kuznets cycles. Entrepreneurs must be willing to pay fixed costs necessary to the establishment of transportation and communication facilities that substantially reduce the marginal cost of settlement. Once the initial barriers are breached, that sets the stage for a prolonged expansion - a free lunch for followers, and of course, some rents for leaders.

Second, the expectations of entrepreneurs are central to the beginning of this process. That does not mean that visionary entrepreneurs "make it all happen" (for example, see Fishlow's, 1965, analysis of patterns of settlement and railroad construction in the antebellum period). But it does mean that rapid settlement must be occurring, or expected to occur soon, to justify large expenditures of resources on infrastructure. Moments of expansion are focal points when immigrants, land speculators, infrastructure builders, and external owners of capital agree that rents can be had from moving quickly into new areas to build and populate them, and/or to connect them to preexisting areas in new ways. The frontier always beckoned as the obvious point of future expansion, but the timing of the great push was 
unknown. Clearly, the origins of long waves cannot be attributed to exogenous technological changes. The technologies for building canals and railroads, or for harvesting the vast prairies of the midwest were developed long in advance of their application. Demand-side explanations for origins (including financial and political events, domestically or abroad) are more plausible as "focal points" for starting or stopping long waves, but it would be hard to argue that uniquely large shocks started long waves. Convergent expectations - often associated with dramatic aggregate-demand shocks (like wars) - seem to be a key ingredient to explaining why some shocks helped to trigger "great pushes" of economic activity or great collapses. Of course, the precise timing of convergent (perhaps mutually-fulfilling) expectations is intrinsically hard to explain convincingly.

Third, in addition to the removal of fixed costs of settlement, persistence of growth seems to be related to economies of agglomeration (city building). Location-specific factor market and product market externalities are the defining characteristic of cities (David and Rosenbloom, 1990). Without such externalities, diseconomies of congestion would prevent cities from ever having formed. Economies of agglomeration fed long waves by creating locations of increasing returns that attracted capital and labor after the initial stage of frontier settlement. Specific historical examples of economies of agglomeration include Boston in the early nineteenth century, which served as a focal point for the financing and operation of early American industry (Hekman, 1980), and Chicago, which acted as a production and distribution gateway connecting the East and West (David and Rosenbloom, 1990).

Fourth, network economies created opportunities for growth within pre-existing frontiers for entrepreneurs who found efficient means of combining activities across production and distribution nodes. During the canal-building era, entrepreneurs who owned anthracite coal fields in Eastern Pennsylvania profited handsomely by financing the construction of a canal to bring those resources in touch with the existing network of transportation and production (Chandler, 1972). In the postbellum era, the construction of railroad trunk lines linking distant points on the map revolutionized the production and distribution of industrial output and the organization of industrial enterprises (Chandler, 1977). The 
revolutions in production, distribution, and marketing during this period, and the creation of the modern corporate form of hierarchical management, were largely a spatial revolution in the economy. Large geographical scope changed the definition of the economy from a collection of local and regional economies to a single national economy, with firms that operated throughout the nation. This transformation largely reflected the economies of operating networks emphasized by Chandler (1977) achieving more efficient larger production scale and high "throughput" by improving management, distribution, and nationwide marketing (Field, 1983, 1987).

Of course, opening new frontiers and building transportation networks and cities were not the only contributing factors in producing long swings. As discussed above, endogenous technological change may have been important as well - particularly in the cases of the textile industry in the early nineteenth century and agricultural growth in the 1850 s. Looking to the future, in an economy with closed geographical boundaries and well-developed transportation networks and urban centers, the relative importance of technological factors is likely to be even greater. Conceivably, the new "frontier" in the American economy may be technological rather than spatial, with new "construction" defined in terms of the "information superhighway." To the extent that convergent expectations and network externalities are important preconditions for realizing technological breakthroughs, Kuznets cycles of the future may be describable more in terms of redesigning existing technologies or networks of communication.

\section{Econometric Lessons}

What are the methodological implications of historical long swings for macroeconometrics? First, as already noted, demand shocks often set in motion long-run changes in aggregate supply, and thus it is wrong to view long-run shifts in supply as independent of momentary demand disturbances. Second, the importance of spatial concepts like cities and frontiers suggest advantages from disaggregation across locations for understanding macroeconomic change. Third, the number of observations of business cycles may be few, even though the number of calendar years of data are many. Once one defines the cycle of 
interest to be of eighteen-year duration, that substantially limits the number of cycles. This suggests further advantages from disaggregation. By relying on panel data (for states and towns, enterprises and individuals), one can exploit cross-sectional variation in the data when testing hypotheses. As we show in the subsequent discussion, recognition of "institutional non-neutrality" reinforces these same methodological implications.

\section{INSTITUTIONAL NON-NEUTRALITY}

Macroeconomic stability and growth may be affected by "institutional innovations," as well as more conventionally defined supply and demand shocks. A discussion of institutional change presumes a definition of institutions. For our purposes we define institutions to include entities that make decisions, or regulate and enforce contracts (such as governments, banks, labor unions and courts), as well as "decision rules" and "coalitions" that may not be embodied in a physical location, formal association, or contract. The most interesting institutions, from the standpoint of macroeconomic history, are those that influence information, resources, tastes and technology, rather than simply reflect them. As Alex Field (1981) has argued, despite the historian's instinct to explain institutional change as a purposeful choice, often institutions, once formed, take on a life of their own. Indeed, Field argues that at any point in time an organized market economy must take as given most of its most important institutional parameters (for example, what constitutes an enforceable contract); otherwise chaos would result.

\section{Labor Markets}

In addition to basic legal and ethical principles on which a market economy must be founded, other institutions play an active role in determining outcomes. In labor contracting, for example (discussed at length above) some macroeconomists and historians have placed great weight on technological changes and the development of unions in affecting the bargaining power of workers, the distribution of wealth, and the "rigidity" of wages. Changes in the integration of labor markets have also 
been emphasized as important preconditions to the settlement of the frontier and the transfer of workers from relatively unproductive occupations to more productive regions and jobs (Field, 1978, Wright, 1979, 1981, 1986, Hatton and Williamson, 1991, Goldin and Sokoloff, 1984, Rosenbloom, 1988, 1990, Sundstrom and Rosenbloom, 1993, Margo, 1994, Simkovich, 1994). Such changes were important determinants of the cross-regional distribution of wealth, and were necessary conditions for rapid expansion phases of the Kuznets cycle.

\section{Capital Markets, Bank Regulation, and Monetary Policy Regimes}

Financial institutional change also had important (largely unintended) effects on the economy. North (1961) argues that the early concentration of capital among New England merchants provided the financing for early industrialization. Special chartering of banks to serve the needs of favored borrowers - the mercantilistic approach of creating rents to spur development - may also have helped to concentrate resources in the hands of early industrialists. Davis $(1957,1960)$ and Lamoreaux (1994) show that New England's manufacturers relied heavily on loans from the banks they controlled as a supplement to retained earnings in financing rapid expansion. Carosso (1970) and Neal (1994) argue - from the financial histories of the U.S. and Britain, respectively - that the development of networks of investment bankers and dealers (often spurred by dramatic events, such as the government's need to finance wars with debt) had long-lived benefits for private costs of external finance. In a similar vein, Calomiris and Raff (1994) argue that the growth of U.S. pension funds and mutual funds in the 1950s and 1960s - largely an unintended benefit of tax policy and demographic changes in the economy - significantly reduced the cost to industrial corporations of raising external funds by reducing the costs of selling common stock.

The literature on the role of bank financing during the postbellum "second industrial revolution" emphasizes the shortcomings of bank regulation - especially restrictions on branching and consolidation within the banking system - and the way restrictions on American banking hindered interregional capital flows, slowed capital accumulation, and promoted instability. The earliest work in this literature (Davis 
1963, 1965, Sylla, 1969, James, 1978, Snowden, 1984) established that American capital markets were highly segmented. Compared to other countries, which operated nationwide branch banking systems, interest rates and profit rates differed greatly across regions and sectors. Interregional profit rate differentials widened in the latter half of the nineteenth century as the geographic scope of the economy and the minimum efficient scale of production expanded rapidly (Chandler, 1977, Calomiris, 1993b, Bodenhorn, 1992, Atack and Bateman, 1994). Small unit banks were unable to meet the needs of the new generation of large firms operating production and distribution networks throughout the country. The participation of banks in industrial finance was relatively small, as banks came to specialize more in financing commercial enterprises. The costs of industrial finance in the United States were much higher than in the concentrated, "universal" banking system of Germany, where large-scale banking permitted greater diversification, as well as the reaping of network and scope economies in placing traded securities, managing trust accounts, and participating in corporate finance and governance of large-scale industrial firms (Calomiris, 1994). ${ }^{12}$ Higher financing costs not only retarded industrial expansion, but also led industrial producers to favor less fixed-capital intensive production processes (Field, 1983, 1987, Wright, 1990, Calomiris, 1994).

Access to bank services in rural areas was also restricted by unit banking laws. Unit banking reduced the profitability of establishing high-overhead banks in sparsely populated areas, which would have been better served by low-overhead branches (Evanoff, 1988). Furthermore, after episodes of local or regional financial distress, states with unit banking laws found it much harder to rebuild their banking systems through acquisitions of failed banks or the establishment of new offices (Calomiris, 1990, 1992, 1993b).

While the mortgage market - which was able to rely on insurance companies for financing apparently overcame some of the barriers to integration posed by unit banking laws, Snowden (1993) and Snowden and Abu-Saba (1994) argue that the fragmentation of the national mortgage market (a by-product of unit banking laws) exacerbated agency problems between mortgage financiers (insurance companies) 
and local brokers, and promoted inefficient allocation of mortgage credit.

The greater instability of the unit banking system - which saw much higher failure rates and a unique propensity for banking panics in comparison with other countries - was also a result of the fragmentation of the financial system that unit banking entailed. Times of trouble for banks both reflected adverse economic conditions, and propagated cyclical disturbances through contractions in the availability of credit (Calomiris and Hubbard, 1989, Calomiris and Gorton, 1991, Grossman, 1993). Other countries enjoyed the benefits of the diversification of risk ex ante, and the coordination of the banking system's response to adversity ex post, which a banking system with a small number of large banks made possible (Calomiris and Gorton, 1991, Calomiris and Schweikart, 1991, Calomiris, 1993b). In addition, unit banking supporters eager to achieve banking stability without allowing branching pushed for the establishment of deposit insurance, which further undermined the stability of the system by encouraging excessive risk taking by banks (White, 1983, Calomiris, 1993b, Calomiris and White, 1994, Wheelock and Kumbhakar, 1994).

Despite the potential benefits of relaxing unit banking restrictions, special interests succeeded in blocking branch banking legislation (White, 1984, Calomiris, 1993b, Calomiris and White, 1994).

Historical "path dependence" played an important role here. Prior to the 1870 s, branch banking was not a contentious issue, and the costs of unit banking were arguably small, since the minimum efficient scale of industrial firms and the geographic scope of the economy were limited up to that point. During the second industrial revolution, as unit banking increasingly became a costly constraint on the economy, the existing special interests of unit bankers and their allies limited the adaptation of the banking system to the new needs of industry, agriculture and commerce.

The consequences of unit banking laws for the financial system helped set the stage for the creation of the Fed in 1913. Like most changes in government financial regulation, the Fed was created in the wake of a crisis - the Panic of 1907 - as a brainchild of the National Monetary Commission, which brought together politicians, bankers, and many of the most prominent financial economists of the time to 
redesign the American banking system. Given the politics of unit banking, however, the Federal Reserve Act avoided dealing with the fragmentation of the banking system, which was understood to be the fundamental source of instability in the system. Instead, the Fed was designed to stabilize the banking system by limiting interbank lending and reducing the seasonal volatility of interest rates.

The Fed was conceived essentially as a microeconomic intervention into the reserve market. It was intended to remedy, first and foremost, the absence of an elastic supply of reserves at seasonal frequency. Given seasonal fluctuations in loan demand - linked to the needs to finance planting, harvesting, and marketing of agricultural produce - banks in the aggregate were forced to choose between allowing seasonal fluctuations in their loan-to-reserve ratio, or importing and exporting gold in large quantities in response to seasonal fluctuations in loan demand. ${ }^{13}$ Gold was costly to import and export (it cost roughly 0.5 percent of the value of gold to bring it across the Atlantic - Officer, 1986). Thus there were strong incentives to allow loan-to-reserve ratios to fluctuate with demand. Seasonal increases in the loan ratio placed banks at greater risk of defaulting on their deposits, and therefore, resulted in the comovement of loan interest rates and loan demand. Thus peak-time borrowers were forced to compensate bankers for the greater portfolio risk to banks during peak periods. Clark (1986), Miron (1986), Barsky et al. (1988), Calomiris and Gorton (1991), and Calomiris and Hubbard (1994b) discuss evidence that prior to the founding of the Fed seasonal fluctuations in U.S. loan demand produced important seasonal fluctuations in U.S. and foreign interest rates, and in flows of foreign capital and gold. The Fed's discount window was intended to provide an elastic supply of reserves at seasonal frequency, thus obviating the need for seasonal interest rate fluctuations or gold flows.

The other main goal of the Fed was to restructure the market for reserves to eliminate "reserve pyramiding" in the banking system (White, 1983). Under unit banking, banks outside of the Eastern financial centers would lend funds to money-center banks during periods of low local loan demand. These funds were used, among other things, to finance the underwriting and trading of securities. Critics of this arrangement argued that it placed the reserves of the entire banking system at excessive risk, since 
problems in securities markets, which sometimes produced losses for investment bankers and money-center banks that lent money to them, could threaten the ability of all banks to repay their depositors. This was not an unwarranted concern. For example, during the Panic of 1857 , and in all the other major financial panics of the national banking era, security market losses in the financial center played an important role in destabilizing the system. Crises during the national banking era tended to be transmitted through the system from the top of the pyramid down (Calomiris and Gorton, 1991, Calomiris and Schweikart, 1991). ${ }^{14}$

The twelve Federal Reserve Banks were intended to substitute as repositories for interbank reserves. The hope was that banks would decide to keep funds with these regional Feds and forego lending to money-center banks. But the Fed failed to accomplish this goal due to two crucial flaws in the design of the system. First, costly regulations of Fed member banks discouraged banks from joining (which became referred to as the "membership problem"). Small banks found that they could reap the advantages of access to the discount window by borrowing from large banks that were Fed members, and so it did not pay them to join the Fed system and pay the high regulatory costs of membership. In this respect, White (1983) argues, the creation of the Fed may have reinforced rather than undermined reserve pyramiding. Second, the Fed did not pay interest on reserves. If it had done so, then large regional member banks would have been willing to deposit funds with the Fed rather than in New York banks. But without an incentive to deposit reserves at the Fed, banks continued their practice of concentrating funds in the East during times of slack local loan demand.

More generally, despite its apparent success in reducing the seasonal volatility of interest rates, the Fed failed as a mechanism to insulate the macroeconomy from deflationary international shocks and disruptive banking collapses, as several waves of banking failures during the 1930 s illustrated. ${ }^{\text {is }}$ The core problems that made the U.S. banking system so fragile - lack of diversifications within, and coordination among, banks - were products of unit banking, and were not addressed by the founding of the Fed. The Fed is a good example of an institution that was designed to accomplish clear objectives, but 
which was hampered by flaws in its design and by the constraints posed by special interests. The Fed is also a good example of Field's (1981) argument that institutions come to take on a life of their own independent of the reasons they came into being. Countercyclical monetary policy, which came to be the Fed's primary occupation, was not one of the principal objectives that gave rise to the Fed.

\section{Do Governments Learn? Institutional Change and the Great Depression}

One way to approach the economic history of the period leading up to and following the Great Depression is to consider it as a case study in institutional "adaptation" to changing circumstances. The emphasis of much of the literature on the period 1929-1935 is that "learning" was occurring - about appropriate monetary policy rules, about the macroeconomic consequences of wage rigidity, about the costs of adherence to the gold standard, and about the remaining weaknesses in the banking system. Interestingly, the recent literature on institutional learning during the Depression does not suggest that, as a general proposition, learning led to improvement in policy. Rather, the record is mixed. In some respects, the right lessons seem to have been learned - particularly with respect to monetary policy rules, the disadvantages of rigid wages, and the potential costs of adherence to the gold standard. In other respects - notably, bank regulatory policy and fiscal policy - recent research suggests that major institutional changes resulting from government intervention were ill-advised and based upon false interpretations of the Depression.

On the positive side, the Fed's approach to monetary policy seems to have changed for the better. The improved concentration of Fed authority in Washington, and greater coordination of decision making within the Fed, which Marriner Eccles championed through his support for the Banking Act of 1935 and his stewardship as Fed Chairman, transformed the Fed into a more effective (though not perfect) maker of monetary policy. Friedman and Schwartz (1963) provided the seminal analysis of policy errors by the Federal Reserve during the Depression, which has been substantially updated by recent research (see the review in Calomiris, 1993c). Friedman and Schwartz argued that Fed money-supply contractions 
produced the Great Depression, and that those errors would not have occurred if Benjamin Strong had remained at the helm of the New York Fed. The thrust of much of the recent work on Fed policy during the interwar period casts doubt on these arguments. Despite strong evidence that monetary policy was contractionary in 1929 (which was not the focus of Friedman and Schwartz's argument), later episodes of monetary contraction seem likely not to have resulted from money-supply shocks. Moreover, Fed policy was constrained by adherence to the gold standard, and by concerns over gold outflows, which limited its reactions to adverse shocks originating elsewhere in the economy (Eichengreen, 1992, 117-119, 296-298). With respect to alleged changes in Fed targeting rules, Wheelock $(1989,1990)$ has shown that the reaction function of the Fed was essentially unchanged before an after the departure of Strong. This reaction function was based on targeting rules of thumb that had proved useful in the past, but which misled the Fed during the Depression. It may be that the Fed's reaction function and its adherence to the gold standard were disastrous during the Depression; however, as Temin (1989) argues, it is hard to blame the Fed for not learning the lessons of the Great Depression before it happened.

The abandonment of the gold standard was another important component of Great Depression "learning" in many countries. Adherence to the gold standard was one of the central tenets of "classical" economic policy (Temin, 1989). The classical approach - whose influence over central banking policy can be traced at least as far as the Peel Act of 1844 in England (Helms, 1939, Wood, 1939) - emphasized the benefits of rules over discretion. A related classical tenet was that recessions were necessary means of forcing resources out of relatively unproductive, older firms, and into new technologies - recessions were the occasional growing pains of capitalism. While these tenets may have merit, slavish adherence to simplistic rules, or the belief that recessions are always good for the economy, can have drastic adverse consequences - this was an important lesson of the Great Depression. Countries that abandoned gold in 1931 to halt the free fall in their economies avoided the worst of the collapse of the Great Depression, while those that retained their ties to gold suffered worsening deflation, bankruptcy, and economic disaster (Eichengreen and Sachs, 1985, 1986, Temin, 1989, Bernanke and James, 1991, Eichengreen, 1992, 
Bernanke, 1994). Ironically, in some cases (notably Germany) earlier experience with hyperinflation had led governments to establish new mechanisms in the 1920 s to prevent discretionary relaxation of the gold standard (Eichengreen, 1992, 125-152, 273-277). This illustrates the difficulty of applying lessons from history. The shocks of the future are not always the same as those of the past.

Eichengreen (1992) argues that the lesson of the interwar collapse under the gold standard was not that the gold standard per se is a bad system, but rather, that the successful maintenance of the gold standard requires coordination among countries to prevent destabilizing exchange market disequilibrium. According to this view, the classical gold standard operated well largely because of coordination among the major central banks of Europe - in Britain, France, and Germany -- who acted together to reinforce each other's actions. This lent credibility to any one country's policies, and discouraged private capital from taking positions opposite central banks (i.e., engaging in speculative attacks on a currency). This may have been an important contributor to the ease of international capital flows, and the small differences in money-market interest rates across countries (Calomiris and Hubbard, 1994b).

While the postwar Bretton Woods system claimed to offer the possibility of both adherence to rules and (contrary to the gold standard) the flexibility of controlling the overall supply of the unit of account (i.e., the dollar), it did not provide effective checks and balances to coordinate monetary policy among the participants. The lack of discipline on U.S. monetary policy, in particular, turned out to be an important omission, which led to the demise of the system (Bordo and Eichengreen, 1993). In that sense, the lessons of the collapse of the gold standard were not learned - in retrospect, the classical gold standard of the pre-World War I era remains the most successful example of how flexibility in response to crises can be combined with long-run adherence to rules in an international monetary system (Bordo and Kydland, 1990, Eichengreen, 1992). In this respect, history has been "regressive."

One example of progress in economic thinking and economic policy after the 1930 s - which may have reflected the experience of the Depression - is the demise of the doctrine of high wages, which seems to have no adherents currently. According to this doctrine, resisting wage cuts during recessions is 
a desirable macroeconomic policy because it keeps workers' consumption high (O'Brien, 1989). This argument is logically flawed - while it may be beneficial for individual firms to maintain high wages in the face of a declining demand for labor (as in some New Keynesian arguments about efficiency wages), in the aggregate this will have a negative effect on output, not the positive effect claimed by supporters of the doctrine of high wages. Nevertheless, this doctrine was widely believed as late as the 1930 s.

The Depression may have illustrated problems with some existing policy rules and prescriptions, but it also provided fertile political ground for flawed economic analyses and policies. Two prominent examples include the many changes in the regulation of banks, and the taxation of corporations. In the latter case, the Surtax on Undistributed Profits of 1936 is a prime example. Berle and Means (1932) suggested that lack of discipline over corporate management could lead to wasteful use of shareholders resources. Some proponents of the classical view of business cycles carried that argument further and argued that declining industries had contributed to the Depression by refusing to pay out their earnings to stockholders, which limited resources available to finance new, more productive enterprises. The proposed solution was the Surtax on Undistributed Profits, which taxed firms up to a marginal surtax rate of 27 percent on retained earnings (defined as net earnings less dividends, calculated after the payment of normal corporate taxes). Corporations opposed the tax from the beginning. Ironically, the most bitter opponents of the tax were corporations in high-growth sectors, which tended to face high costs of raising external funds. For these firms, taxation of retained earnings imposed a large cost on their primary means for financing growth (Calomiris and Hubbard, 1994a). Compared to the presumed gains from enhancing corporate discipline, these costs were enormous. Fully 20 percent of taxpaying firms - typically small, growing firms in high-growth industries - chose to pay marginal surtax rates of at least 22 percent to be able to retain earnings. The opposition to the Surtax effectively won repeal of the measure after only two years.

The attack on the banking system, based on what proponents claimed were lessons from the Depression, was much more far-reaching and long-lived. The Banking Act of 1933 fundamentally 
changed the structure of financial institutions, and its key provisions remained essentially unchanged for six decades. ${ }^{16}$ Many of the changes in 1933 were policies that had long been contemplated and rejected by Congress (like federal deposit insurance). Others were variations on old themes. For example, the separation between commercial and investment banking, and Regulation $Q$, were the brainchildren of Senator Carter Glass. Glass echoed decades of previous arguments about bank instability when he argued that banks' involvement in the securities market, and the pyramiding of reserves, had promoted the banking collapse and the Depression of the 1930s. There were also accusations of fraud or conflict of interest in commercial bank marketing of the securities they underwrote. In addition to the separation of commercial and investment banking, Glass argued for Regulation Q (which prohibited the payment of interest on demand deposits) as a way to discourage banks from depositing funds in other banks. Ironically, recent empirical evidence points to stabilizing effects from combining commercial and investment banking prior to the Depression, and there is no evidence of conflict of interest in doing so (Kroszner and Rajan, 1994). White (1986) found that banks with securities affiliates had lower probabilities of failure and enjoyed greater diversification of earnings. Kroszner and Rajan (1994) found that the ex post performance of investments in securities underwritten by banks were at least as good as for other securities. Benston (1989) argues that there was never really any evidence unearthed by Congress that pointed to a destabilizing influence from underwriting, or to a pattern of conflict of interest. Congress never bothered with the evidence. The coincidence of the banking collapse of 1931-1933 and the stock market collapse of 1929 provided all the evidence Congress needed to make its decision.

While Glass did not support the creation of federal deposit insurance, his Senate Banking Committee's Pecora Hearings served to buttress the case for deposit insurance made by his opponents, Congressman Henry Steagall and Senator Huey Long. They used the Pecora Hearings as evidence that a banking system based on large-scale banks was prone to crisis, arguing that commercial banks in financial centers were the source of excessive speculation that had led to the Depression. Unit bankers, in contrast, were - like the public - portrayed as the victims of speculative excess. Steagall, Long, and their allies 
succeeded in making banking reform a central issue in the forum of public debate. Despite the enormous losses and evidence of moral-hazard problems in state-level deposit insurance systems of the 1920s (White, 1983, Calomiris, 1990, 1992, 1993b), and despite the opposition of Glass, Roosevelt, the Federal Reserve, and the Treasury, advocates of deposit insurance, and capital assistance to banks through the Reconstruction Finance Corporation, pushed through legislation resuscitating unit banks and effectively restricting bank consolidation (Flood, 1991, Calomiris and White, 1994). Steagall's success was one of the most impressive examples of legislative maneuvering in the history of Congressional politics.

To sum up, economic doctrine and regulation are important state variables for determining macroeconomic outcomes. The Great Depression illustrates how false beliefs and wrong-headed policies can emerge during times of crisis. Crisis-induced changes often are not clearly thought through, and may reflect motives that have more to do with political opportunism than with social welfare. Ill-advised institutional changes can have large and persistent costs because of the difficulty of reversing them. The persistence of inefficient institutions can reflect the operation of special interests which defend the institution (as in unit banking) or the protracted process of "social learning" about the costs of institutions (as in Fed targeting in the interwar period, and the rigid adherence to gold standard rules in many countries during 1929-1933).

\section{Econometric Lessons}

The methodological message of institutional non-neutrality for econometrics is similar to that of the "Lucas critique," which was formulated as a criticism of macroeconomic modeling which does not take proper account of changes in behavior that follow from changes in policy. Institutional changes are another dimension of behavioral response to policy, but much more. They also alter decision making in manners similar to monetary and fiscal policy, and they define and constrain the realms in which decisions are made.

Institutions have been important in economic history, both as sources of disturbance and as 
propagators of shocks that originate elsewhere, and it is likely that institutional effects have been particularly important in explaining low-frequency economic change. Institutional change has been associated with changes in the averages of important macroeconomic variables (like inflation or unemployment) over long periods of time, as well as the variance-covariance structure of macroeconomic variables at cyclical and seasonal frequency. Some of the clearest examples are the changes in seasonal credit patterns associated with the creation of the Federal Reserve System and the changes in the inflation process that have accompanied different monetary regimes (the gold standard, the greenback suspension, and the current fiduciary standard). Less clearcut, more gradual institutional changes have been important as well - for example, Fed learning about monetary targeting during the Great Depression, and the movement away from a unit banking system in the 1980s and 1990s.

The institutional history of a nation is difficult to define as an aggregate variable, much less to control for when analyzing time series aggregates. Such a task is particularly difficult given the frequent changes in institutions that take place. But in disaggregated data, and in comparisons across countries, one can exploit cross-sectional variation to test for, and control for, the importance of institutional effects. In this respect, the methodological lessons of institutional non-neutrality are quite similar to those of long swings.

\section{v. CONCLUSION}

In what ways do the facts of the past confirm and challenge macroeconomists' existing models of the economy today? Available statistical evidence on the cyclical properties of prices, wages, and other variables, as well as historical evidence on the pace of technological change, are consistent with traditional explanations of business cycles that revolve around shocks to aggregate demand as the most important sources of economic fluctuation.

That does not mean that mainstream macroeconomic models based on sticky wages and prices, or statistical analyses of time series aggregates suggested by those models, provide a complete explanation of 
American macroeconomic history. Perhaps surprisingly, the new frontiers of macroeconomics remain the old frontiers that have been beckoning for half a century. In particular, economists still lack a full understanding of the history of low-frequency cycles and severe, long-lived depressions.

Despite all that we have learned about the history of the economy, and about the sources of shocks during the 1930 s in particular, macroeconomists still lack a fully satisfying explanation of the protracted duration of high unemployment and excess capacity during the Depression. More generally, standard macroeconomic analysis, which focuses on high-frequency cycles produced by transitory demand shocks, has neglected the phenomena surrounding Kuznets cycle - cycles of 18-year duration that are associated with waves of new settlement, construction activity, city building, and migration.

The lack of attention to low-frequency cycles is an important gap in our knowledge about the economy. Anyone attempting to provide a concise summary of American economic development will find himself essentially plotting out the Kuznets cycle. During the nineteenth and early twentieth centuries, especially, as America pushed back the physical frontier westward, building cycles were central to the process of territorial expansion and industrialization. Migration, construction, and other related investment depended upon each other and were prone to sustained progress, as well as rapid reversal.

New work in the endogenous growth literature has led macroeconomists back to the threshold of studying long swings by emphasizing the long duration of disturbances to economic activity, and it is likely that models of economic growth that consider product and factor market externalities and nonconvexities in production may be useful for understanding long-duration cycles. Perhaps the main contribution an historical view of the economy can make to this research program is to suggest the importance of spatially and sectorally defined processes, as well as institutional change, for understanding long swings. For example, economies of agglomeration (city building) provide a natural way to think about endogenous growth that maps nicely into the history of the expansion of the American frontier and the construction cycle. Such economies should show themselves in particular places and particular sectors at particular points in time. Aggregate time series analysis, therefore, should be supplemented with 
analysis of specific historical circumstances when judging the applicability of new models of economic growth to American history.

Other factors suggested by Schumpeter (1939) - who practically invented the idea that shocks to aggregate demand can lead to irreversible changes in long-run growth - are likely to be important, as well. Such irreversibilities may include migration of laborers, the creation or destruction of banks and the destruction of firms' net worth (which can be thought of as changes in financial technology, as argued by Bernanke, 1983), or demand-induced irreversible changes in production technology (e.g., "shake-out" associated with the closing of factories). Severe contractions in demand may produce long-lasting "structural" unemployment of resources as well as technological change - as in the automobile industry in the 1930s (Bresnahan and Raff, 1991).

For all these reasons, we believe that economists interested in low-frequency change are likely to find it useful to disaggregate time series data to examine the behavior of particular locations, sectors, and types of workers over the business cycle. The answers to important questions like "what shocks prompt business cycles?" or "what sorts of environments produce greater wage rigidity?" are not likely to come from the latest econometric twist in analyzing the same old time series data. We think it is more likely that answers will come from constructing new data designed to answer specific questions (with a panel dataset), from appeal to simple examples (for example, when considering the likely importance of exogenous technological change in producing high-frequency variation in output), and from historically informed comparisons across well-defined regimes (as we argued in our analysis of labor market rigidities).

The work of Eichengreen and Sachs (1985, 1986), Bernstein (1987), Margo (1993), Wallis (1989), Bresnahan and Raff (1991), Bernanke and James (1991), Calomiris and Hubbard (1994), and Bernanke (1994) on the Great Depression exemplify such a research agenda. All of these papers have in common the use of cross-sectional variation to identify important macroeconomic shocks and propagators during the Depression. Margo and Wallis focus on the question of how employment supply shifted in response to 
New Deal programs. Bresnahan and Raff show how the Depression produced important endogenous technological responses to the collapse of aggregate demand. Bernstein argues that cross-sectional variation in the performance of different sectors is consistent with significant changes in consumer demand brought on by the Depression. Bernanke and James and Calomiris and Hubbard use cross-country and cross-firm differences to link debt deflation and capital market constaints to the collapse of investment.

Macroeconomic history also teaches us that economic institutions are an integral part of macroeconomic history and important contributors to "path-dependent" economic change. The Federal Reserve System is a particularly important example. Like other important changes in institutions, its origins can be traced to an adverse macroeconomic event. The Fed fell short of achieving the objectives it was designed to achieve because its powers and the structure of the banking system were constrained by other institutional arrangements - the gold standard and preexisting unit banking. Over time, and in response to other events, the structure or operating rules of the Fed have changed dramatically (for example, in 1935, 1951, and 1979), often with significant macroeconomic consequences.

Trying to model and measure the impact of institutional change, and test explanations of institutional change, are challenges that have mainly been ignored by macroeconomists and macroeconometricians. "Endogenizing" institutions, and tracing the long-run macroeconomic implications of specific institutional changes, pose formidable challenges to macroeconomic theory and measurement; but the alternative - pretending that institutional change is an irrelevant sideshow - has nothing to recommend it except the bliss of ignorance.

Donald McCloskey sometimes argues that Ph.D. students are the only audience of economists worth addressing. With that advice in mind, we conclude with a list of recommendations for students willing to brave the frontiers of macroeconomic history. (1) Interesting questions about macroeconomic history often flow from an understanding of the lives of real people. It does not hurt to become acquainted with facts other than statistics. (2) Research that addresses questions posed by models is not usually as interesting as research that addresses questions posed by historical data or events. (3) Searching 
history for controlled "experiments" to test models is a fine occupation, so long as the history surrounding the "experiments" is not viewed as incidental to the exercise. (4) Scholars should not be afraid to tell and defend stories on grounds of plausibility. Stories are no substitute for logic or facts, but without them, economics is a rudderless ship. Researchers should look to the past as a check against intellectual fads, as a source of controlled experiments, and as a fountain of wisdom about how economies develop in real time. 


\section{REFERENCES}

Abramovitz, Moses, Evidence of Long Swings in Aggregate Construction since the Civil War, New York: Columbia University Press, 1964.

Allen, Steven G., "Changes in the Cyclical Sensitivity of Wages in the United States, 1891-1987," American Economic Review 82, March 1992, 122-140.

Alogoskoufis, George S., and Smith, Ron, "The Phillips Curve, the Persistence of Inflation, and the Lucas Critique: Evidence from Exchange-Rate Regimes," American Economic Review 81, December 1991, 1254 1275.

Atack, Jeremy, and Fred Bateman, "Did the United States Industrialize Too Slowly?," Working paper, Vanderbilt University, July 1994.

Atack, Jeremy, Bateman, Fred and Weiss, Thomas, "The Regional Diffusion and Adoption of the Steam Engine in American Manufacturing," Journal of Economic History 40, June 1980, 281-308.

Azariadis, Costas, "Implicit Contracts and Fixed price Equilibria," Quarterly Journal of Economics 98, 1983 Supplement, 1-22.

Backus, David K. and Kehoe, Patrick J., "International Evidence on the Historical Properties of Business Cycles," American Economic Review 82, September 1992, 864-888.

Balke, Nathan S. and Gordon, Robert J., "The Estimation of Prewar Gross National Product: Methodology and New Evidence," Journal of Political Economy 97, February 1989, 38-92.

Barro, Robert J., "Second Thoughts on Keynesian Economics," American Economic Review 69, May 1979, 54-59.

Barro, Robert J., "Output Effects of Government Purchases," Journal of Political Economy 89, December 1981, 1086-1121.

Barro, Robert J., "Government Spending, Interest Rates, Prices, and Budget Deficits in the United Kingdom, 1701-1918," Journal of Monetary Economics 20, September 1987, 221-248.

Barro, R. J., and King, R. G., "Time-Separable Preferences and Intertemporal Substitution Models of the Business Cycle," Quarterly Journal of Economics 99, November 1984, 817-39.

Barsky, Robert B., Mankiw, N. Gregory, Miron, Jeffrey A., and Weill, David N., "The Worldwide Change in the Behavior of Interest Rates and Prices in 1914," European Economic Review 32, 1988, 1123-1154.

Benhabib, Jess, Rogerson, Richard and Wright, Randall, "Homework in Macroeconomics: Household production and Aggregate Fluctuations," Journal of Political Economy 99, 1991, 1166-1187.

Benston, George J., The Separation of Commercial and Investment Banking: The Glass-Steagall Act Revisited and Reconsidered, Norwell, MA: Kluwer Academic, 1989. 
Berle, Adolph A., and Means, Gardiner, The Modern Corporation and Private Property, New York: Columbia University Press, 1932.

Bernanke, Ben S., "Nonmonetary Effects of the Financial Crisis in the Propagation of the Great depression," American Economic Review 73, June 1983, 257-276.

Bernanke, Ben S., "The Macroeconomics of the Great Depression: A Comparative Approach," NBER Working Paper No. 4814, August 1994.

Bernanke, Ben S., and James, Harold, "The Gold Standard, Deflation, and Financial Crisis in the Great Depression," in R. Glenn Hubbard, ed., Financial Markets and Financial Crises, Chicago: University of Chicago Press, 1991, 33-68.

Bernanke, Ben S., and Parkinson, Martin L., "Procyclical Labor Productivity and Competing Theories of the Business Cycle: Some Evidence from Interwar U.S. Manufacturing Industries," Journal of Political Economy 99, 1991, 439-459.

Bernanke, Ben S. and Powell, James L., "The Cyclical Behavior of Industrial Labor Markets: A Comparison of the Prewar and Postwar Eras," in Robert J. Gordon, ed., The American Business Cycles: Continuity and Change, Chicago: University of Chicago Press, 1986, 583-638.

Bernstein, Michael A., The Great Depression: Delayed Recovery and Economic Change in America, 1929 1939, Cambridge: Cambridge University Press, 1987.

Bils, Mark, "Pricing in a Customer Market," Quarterly Journal of Economics 104, November 1989, 699-718.

Blanchard, Olivier and Kiyotaki, Nobuhiro, "Monopolistic Competition and the Effects of Aggregate Demand," American Economic Review 77, September 1987, 647-666.

Blanchard, Olivier J., and Quah, Danny, "The Dynamic Effects of Aggregate Demand and Supply Disturbances, Working paper, Massachusetts Institute of Technology, 1988.

Blanchard, Olivier J., and Summers, Lawrence H., "Why is Unemployment So High in Europe? Beyond the Natural Rate Hypothesis," American Economic Association Papers and Proceedings, May 1988, 182187.

Bodenhorn, Howard, "Capital Mobility and Financial Integration in Antebellum America," Journal of Economic History 52, September 1992, 585-610.

Bordo, Michael D., and Eichengreen, Barry, eds., A Retrospective on the Bretton Woods System: Lessons for International Monetary Reforms, Chicago: University of Chicago Press, 1993.

Bordo, Michael D., and Kydland, Finn, "The Gold Standard as a Rule," Working paper, Rutgers University, 1990.

Bowley, A. L., "Tests of National Progress," Economic Journal 14, September 1904, 457-465. 
Bresnahan, Timothy F., and Raff, Daniel M.G., "Intra-industry Heterogeneity and the Great Depression: The American Motor Vehicles Industry, 1929-1935," Journal of Economic History 51, June 1991, 317-331.

Bullard, James B., "How Reliable Are Inflation Reports?", Monetary Trends, Federal Reserve Bank of St. Louis, February 1994, 1.

Burns, Arthur F., "Mitchell on What Happens During Business Cycles," in Conference on Business Cycles, New York: National Bureau of Economic Research, 1951, 3-33.

Cagan, Phillip, "Changes in the Recession Behavior of Wholesale Prices in the 1920s and Post-World War II," Explorations in Economic Research 2, Winter 1975, 54-104.

Calomiris, Charles W., "Institutional Failure, Monetary Scarcity, and the Depreciation of the Continental," Journal of Economic History 48, March 1988a, 47-68.

Calomiris, Charles W., "Price and Exchange Rate Determination During the Greenback Suspension," Oxford Economic Papers 40, December 1988b, 719-750.

Calomiris, Charles W., "Is Deposit Insurance Necessary? A Historical Perspective," Journal of Economic History 50, June 1990, 283-295.

Calomiris, Charles W., "Do 'Vulnerable' Economies Need Deposit Insurance: Lessons from the U.S. Agriculture in the 1920s," in Philip L. Brock, ed., If Texas were Chile: A Primer on Banking Reform, San Francisco: Institute for Contemporary Studies, 1992, 237-315, 450-458.

Calomiris, Charles W., "Greenback Resumption and Silver Risk: The Economics and Politics of Monetary Regimes Change in the United States, 1862-1900," in M. D. Bordo and Forrest Capie, eds., Monetary Regimes in Transition, Cambridge: Cambridge University Press, 1993a, 86-132.

Calomiris, Charles W., "Regulation, Industrial Structure, and Instability in U.S. Banking: An Historical Perspective," in Michael Klausner and Lawrence J. White, eds., Structural Change in Banking, Homewood, IL: Business-One Irwin, 1993b, 19-116.

Calomiris, Charles W., "Financial Factors in the Great Depression," Journal of Economic Perspectives 7 , Spring 1993c, 61-85.

Calomiris, Charles W., "The Costs of Rejecting Universal Banking: American Finance in the German Mirror, 1870-1914," in Naomi Lamoreaux and Daniel Raff, eds., Coordination and Information: Historical Perspectives on the Organization of Enterprise, Chicago: University of Chicago Press, 1994, forthcoming.

Calomiris, Charles W., and Gorton, Gary, "The Origins of Banking Panics: Models, Facts, and Bank Regulation," in R. Glenn Hubbard, ed., Financial Markets and Financial Crises, Chicago: University of Chicago Press, 1991, 109-73.

Calomiris, Charles W. and Hanes, Christopher, "Consistent Output Series for the Antebellum and Postbellum Periods: Issues and Preliminary Results," Journal of Economic History 54, June 1994, 409422. 
Calomiris, Charles W., and Hubbard, R. Glenn, "Price Flexibility, Credit Availability, and Economic Fluctuations: Evidence from the United States, 1894-1909," Quarterly Journal of Economics 104, February 1989, 429-52.

Calomiris, Charles W., and Hubbard, R. Glenn, "Internal Finance and Investment: Evidence from the Undistributed Profits Tax of 1936-1937," Working paper, University of Illinois, August 1994a.

Calomiris, Charles W., and Hubbard, R. Glenn, "International Adjustment under the Classical Gold Standard: Evidence from the U.S. and Britain, 1879-1914, " in Bayoumi and Eichengreen, eds., Modern Perspectives on the Gold Standard, 1994b.

Calomiris, Charles W., and Mason, Joseph R., "Contagion and Bank Failures during the Depression: The June 1932 Chicago Banking Panic," Working paper, University of Illinois, September 1994.

Calomiris, Charles W., and Raff, Daniel M.G., "The Evolution of Market Structure, Information, and Spreads in American Investment Banking," in M.D. Bordo and R. Sylla, eds., Anglo-American Finance, Homewood, IL: Irwin, 1994, forthcoming.

Calomiris, Charles W., and Schweikart, Larry, "The Panic of 1857: Origins, Transmission, and Containment," Journal of Economic History 51, December 1991, 807-834.

Calomiris, Charles W., and White, Eugene N., "The Origins of Federal Deposit Insurance," in Claudia Goldin and Gary D. Libecap, eds., The Regulated Economy: A Historical Approach to Political Economy, Chicago: University of Chicago Press, 1994, 145-188.

Carlton, Dennis W., "The Rigidity of Prices," American Economic Review 76, September 1986, 637-658.

Carosso, Vincent, P., Investment Banking in American: A History, Cambridge, MA: Harvard University Press, 1970.

Carter, Susan B. and Sutch, Richard, "The Labour Market in the 1890's: Evidence from Connecticut Manufacturing," in Erik Aerts and Barry Eichengreen, eds., Unemployment and Underemployment in Historical Perspective, Studies in Social and Economic History Volume 12, Leuven University Press, 1990.

Chandler, Alfred D., "Anthracite Coal and the Beginnings of the Industrial Revolution in the United States," Business History Review 46, Summer 1972, 141-181.

Chandler, Alfred D., The Visible Hand: The Managerial Revolution in American Business, Cambridge: Harvard University Press, 1977.

Christiano, Lawrence J. and Eichenbaum, Martin, "Current Real-Business-Cycle Theories and Aggregate Labor-Market Fluctuations," American Economic Review 82, June 1992, 430-450.

Clark, Truman A., "Interest Rate Seasonals and the Federal Reserve," Journal of Political Economy 94, February 1986, 76-125.

Cooley, Thomas F. and Ohanian, Lee E., "The Cyclical Behavior of Prices," Journal of Monetary Economics 28, August 1991, 25-60. 
Crucini, Mario J., "Sources of Variation in Real Tariff Rates: The United States, 1900-1940," American Economic Review 84, June 1994, 732-744.

David, Paul A., Technical Choice, Innovation, and Economic Growth: Essays on American and British Experience in the Nineteenth Century, New York: Cambridge University Press, 1975.

David, Paul A., "The Dynamo and the Computer: An Historical Perspective on the Modern Productivity Paradox," American Economic Review 80, May 1990, 355-361.

David, Paul A., "Economic History Association Presidential Address," Working paper, Stanford University, 1991.

David, Paul A., and Rosenbloom, Joshua L., "Marshallian Factor Market Externalities and the Dynamics of Industrial Location," Journal of Urban Economics 28, 349-370.

Davis, Lance E., "Sources of Industrial Finance: The American Textile Industry, A Case Study," Explorations in Entrepreneurial History 9, 1957, 190-203.

Davis, Lance E., "The New England Textile Mills and the Capital Markets: A Study of Industrial Borrowing," Journal of Economic History 20, 1960, 1-30.

Davis, Lance, E., "Capital Immobilities and Finance Capitalism: A Study of Economic Evolution in the United States," Explorations in Entrepreneurial History 15, Fall 1963.

Davis, Lance E., "The Investment Market, 1870-1914: The Evolution of a National Market," Journal of Economic History 25, September 1965, 355-393.

Dawley, Allen, Class and Community: The Industrial Revolution in Lynn Massachusetts, Cambridge, MA: Harvard University Press, 1976.

DeLong, J. Bradford, "Did J.P. Morgan's Men Add Value? An Economist's Perspective on Financial Capital ism," in Peter Temin, ed., Inside the Business Enterprise: Historical Perspectives on the Use of Information, Chicago: University of Chicago Press, 1991, 205-236.

DeLong, J. Bradford and Summers, Lawrence, "The Changing Cyclical Variability of Economic Activity in the United States," in Robert J. Gordon, ed., The American Business Cycle: Continuity and Change, Chicago: University of Chicago Press, 1986, 679-732.

Devine, Warren D., "From Shafts to Wires: Historical Perspectives on Electrification," Journal of Economic History 43, June 1983, 347-372.

Dickens, William T. and Katz, Lawrence F., "Inter-Industry Wage Differences and Industry Characteristics," in Kevin Lang and Jonathan S. Leonard, eds., Unemployment and the Structure of Labor Markets, New York: Basil Blackwell, 1987, 48-89.

Diebold, Francis X., and Rudebusch, Glenn D., "Have Postwar Economic Fluctuations Been Stabilized?" American Economic Review 82, September 1992, 993-1005. 
Dunlop, John, "The Movement of Real and Money Wage Rates," Economic Journal 48, September 1938, 413-34.

Easterlin, Richard, "Economic-Demographic Interactions and Long Swings in Economic Growth," American Economic Review 56, December 1966.

Eichengreen, Barry, "Macroeconomics and History," in Alexander Field, ed., The Future of Economic History, Boston: Kluwer Nijhoff, 1987, 43-90.

Eichengreen, Barry, Golden Fetters: The Gold Standard and the Great Depression, 1919-1939, Oxford: Oxford University Press, 1992.

Eichengreen, Barry, and Jeffrey Sachs, "Exchange Rates and Economic Recovery in the 1930s," Journal of Economic History 45, December 1985, 925-46.

Eichengreen, Barry, and Jeffrey Sachs, "Competitive Devaluation in the Great Depression: A Theoretical Reassessment," Economic Letters 22, 1986, 67-71.

Evanoff, Douglas D., "Branch Banking and Service Accessibility," Journal of Money, Credit and Banking 20, May 1988, 191-202.

Evans, Paul, "Do Large Deficits Produce High Interest Rates," American Economic Review 75, March 1985, 68-87.

Field, Alexander J., "Sectoral Shift in Antebellum Massachusetts: A Reconsideration," Explorations in Economic History 15, April 1978, 146-171.

Field, Alexander J., "The Problem with Neoclassical Institutional Economics: A Critique with Special Reference to the North/Thomas Model of Pre-1500 Europe," Explorations in Economic History 18, April $1981,174-198$.

Field, Alexander J., "Land Abundance, Interest/Profit Rates and Nineteenth-Century American and British Technology," Journal of Economic History 42, June 1983, 405-431.

Field, Alexander J., "Modern Business Enterprise as a Capital-Saving Innovation," Journal of Economic History 46, June 1987, 473-485.

Fishlow, Albert, American Railroads and the Transformation of the Ante-Bellum Economy, Cambridge: Harvard University Press, 1965.

Flood, Mark D., "The Great Deposit Insurance Debate," Federal Reserve Bank of St. Louis Review 74, July-August 1991, 51-77.

Fogel, Robert William, Railroads and American Economic Growth: Essays in Econometric History, Baltimore: The Johns Hopkins Press, 1964.

Frickey, Edwin, Economic Fluctuations in the United States, Cambridge: Harvard University Press, 1942.

Frickey, Edwin, Production in the United States 1860-1914, Cambridge: Harvard University Press, 1947. 
Friedman, Milton, "Price, Income and Monetary Changes in Three Wartime Periods," American Economic Review, May 1952.

Friedman, Milton and Schwartz, Anna Jacobson, A Monetary History of the United States 1867-1960, Princeton: Princeton University Press, 1963.

Gallman, Robert, "Commodity Output, 1839-1899," in Trends in the American Economy in the Nineteenth Century, NBER Studies in Income and Wealth, Vol. 24, New York: Columbia University Press, 1960, 13-71.

Gallman, Robert, "Gross National Product in the United States, 1834-1909," in Output, Employment and Productivity in the United States after 1800, NBER Studies in Income and Wealth, Vol. 30, New York: Columbia University Press, 1966, 3-90.

Goldin, Claudia, and Engerman, Stanley, "Seasonality in Nineteenth Century American Labor Markets," in Donald Schaefer and Thomas Weiss, eds., Economic Development in Historical Perspective, Stanford, CA: Stanford University Press, 1993.

Goldin, Claudia, and Margo, Robert, "Wages, Prices, and Labor Markets Before the Civil War," in Claudia Goldin and Hugh Rockoff, eds., Strategic Factors in Nineteenth Century American Economic Development, Chicago: University of Chicago Press, 1992.

Goldin, Claudia, and Sokoloff, Kenneth, "The Relative Productivity Hypothesis of Industrialization: The American Case, 1820 to 1850," Quarterly Journal of Economics 69, August 1984.

Gordon, Robert J., "Output Fluctuations and Gradual Price Adjustment," Journal of Economic Literature 19, June 1981, 493-530.

Gordon, Robert J., "Introduction: Continuity and Change in Theory, Behavior, and Methodology," in Robert J. Gordon ed., The American Business Cycle: Continuity and Change, University of Chicago Press, 1986, 1-33.

Gordon, Robert J., "What is New-Keynesian Economics?," Journal of Economic Literature 28, September 1990, $1115-1171$.

Greenwood, Jeremy, Hercowitz, Z. and Huffman, G. W., "Investment, Capacity Utilization, and the Real Business Cycle," American Economic Review 78, June 1988, 402-417.

Grossman, Richard S., "The Macroeconomic Consequences of Bank Failures under the National Banking System," Explorations in Economic History 30, July 1993, 294-320.

Hanes, Christopher, "The Development of Nominal Wage Rigidity in the Late 19th Century," American Economic Review 83, September 1993, 732-756.

Hanes, Christopher, "Changes in the Cyclical Behavior of Nominal Prices, 1869-1990," University of Pennsylvania Working Paper, 1994.

Hansen, Gary D. and Prescott, Edward C., "Did Technology Shocks Cause the 1990-1991 Recession?" American Economic Review May 1993, 280-286. 
Harley, C. Knick, "Oligopoly Strategy and the Timing of American Railroad Construction," Journal of Economic History 42, December 1982, 797-824.

Hatton, Timothy J., and Williamson, Jeffrey G., "Wage Gaps between Farm and City: Michigan in the 1890s," Explorations in Economic History 28, October 1991, 381-408.

Hekman, John S., "The Product Cycle and New England Textiles," Quarterly Journal of Economics 95, June 1980, 697-717.

Helms, Lloyd A., The Contributions of Lord Overstone to the Theory of Currency and Banking, Urbana: University of Illinois Press, 1939.

Hicks, John R. "Mr. Keynes and the 'Classics': A Suggested Interpretation," Econometrica 5, 1937, 147-159.

Hughes, Jonathan, The Governmental Habit Redwx: Economic Controls from Colonial Times to the Present, Princeton: Princeton University Press, 1991.

Hughes, Jonathan, American Economic History, Third Edition, Glenview, IL: Scott, Foresman, 1990.

Hultgren, Thor, "Changes in Labor Cost During Cycles in Production and Business," National Bureau of Economic Research Occasional Paper 74, 1960.

Jacoby, Sanford, Employing Bureaucracy: Managers, Unions, and the Transformation of Work in American Industry, 1900-1945, New York: Columbia University Press, 1985.

Jacoby, Sanford, and Sharma, Sunil, "Employment Duration and Industrial Labor Mobility in the United States, 1880-1980," Journal of Economic History 52, March 1992, 161-179.

James, John A., Money and Capital Markets in Postbellum America, Princeton: Princeton University Press, 1978.

James, John A., "The Stability of the 19th-Century Phillips Curve Relationship," Explorations in Economic History 26, April 1989, 117-134.

James, John A., "Changes in Economic Instability in 19th-Century America," American Economic Review 83, September 1993, pp. 710-731.

Katz, Lawrence F. and Summers, Lawrence H., "Industry Rents: Evidence and Implications, " Brookings Papers: Microeconomics 1989, 209-290.

Keynes, John Maynard, A Treatise on Money: Volume II, The Applied Theory of Money (1931), [London: Macmillan, 1953].

Keynes, John Maynard, The General Theory of Employment, Interest, and Money (1936), [New York: Harcourt Brace Jovanovich, 1964].

Keynes, John Maynard, "Relative Movements of Real Wages and Output," Economic Journal 49, March 1939, 35-51. 
Keyssar, Alexander, Out of Work: The First Century of Unemployment in Massachusetts, New York, Cambridge University Press, 1986.

Khan, B. Zorina and Sokoloff, Kenneth L., "'Schemes of Practical Utility': Entrepreneurship and Innovation among 'Great Inventors' in the United States, 1790-1865," Journal of Economic History 53, June 1993, 289-307.

Kindleberger, Charles P., The World in Depression, 1929-1939, Berkeley: University of California Press, 1973.

Kroszner, Randall S., and Rajan, Raghuram, "Is the Glass-Steagall Act Justified? A Study of the U.S. Experience with Universal Banking Before 1933," American Economic Review 84, September 1994, 810832.

Krueger, Alan B. and Summers, Lawrence H., "Reflections on the Inter-industry Wage Structure," in Kevin Lang and Jonathan S. Leonard, eds., Unemployment and the Structure of Labor Markets, New York: Basil Blackwell, 1987, 17-47.

Krugman, Paul, "Increasing Returns and Economic Geography," Journal of Political Economy 99, June $1991,483-499$.

Kydland, Finn and Prescott, Edward, "Business Cycles: Real Facts and a Monetary Myth," Federal Reserve Bank of Minneapolis Quarterly Review 14, Spring 1990, 3-18.

Kuznets, Simon, "Comment" on Joseph Schumpeter, in Conference on Business Cycles, New York: National Bureau of Economic Research, 1951, 155-162.

Lamoreaux, Naomi R., The Great Merger Movement in American Business, 1895-1904, Cambridge: Cambridge University Press, 1985.

Lamoreaux, Naomi R., Insider Lending: Banks, Personal Connections, and Economic Development in Industrial New England, Cambridge: Cambridge University Press, 1994.

Lazear, Edward, "Agency, Earnings Profiles, Productivity and Hours Restrictions," American Economic Review 71, June 1981, 606-620.

Lebergott, Stanley, Manpower in Economic Growth: The American Record since 1800, New York: McGraw-Hill, 1964.

Lerdau, E., "On the Measurement of Tariffs: The U.S. Over Forty Years," Economia Internazionale 10, May 1957, 232-244.

Lindbeck, Assar and Snower, Dennis J., The Insider-Outsider Theory of Employment and Unemployment, Cambridge: MIT Press, 1988.

Lipsey, Robert E., Price and Quantity Trends in the Foreign Trade of the United States, Princeton: Princeton University Press, 1963.

Long, Clarence D. Wages and Earnings in the United States, 1860-1890, Princeton: Princeton University Press, 1960. 
Lucas, Robert E., "Expectations and the Neutrality of Money," Journal of Economic Theory 4, 103-124.

Lucas, Robert E., "Econometric Policy Evaluation: A Critique," Carnegie-Rochester Series on Public Policy 1, 1976.

Lucas, Robert E., and Woodford, Michael, "Real Effects of Monetary Shocks in an Economy with Sequential Purchases," NBER Working Paper No. 4250, January 1993.

Mankiw, N. Gregory, "Small Menu Costs and Large Business Cycles: A Macroeconomic Model of Monopoly," Quarterly Journal of Economics 100, May 1985, 529-539.

Mankiw, N. Gregory, "Real Business Cycles: A New Keynesian Perspective," Journal of Economic Perspectives 3, Summer 1989, 79-90.

Mankiw, N. Gregory, "A Quick Refresher Course in Macroeconomics," Journal of Economic Literature 28, December 1990, 1645-1660.

Mansfield, Edwin, "Technical Change and the Rate of Imitation," Econometrica 29, October 1961, 741-766.

Mansfield, Edwin, "Long Waves and Technological Innovation," American Economic Association Papers and Proceedings 73, May 1983, 141-145.

Manuelli, Rodolfo E., "Modern Business Cycle Analysis: A Guide to the Prescott-Summers Debate," Federal Reserve Bank of Minneopolis Quarterly Review 10, Fall 1986, 3-8.

Margo, Robert A., "Unemployment in 1910: Some Preliminary Findings," in Erik Aerts and Barry Eichengreen, eds., Umemployment and Underemployment in Historical Perspective, Studies in Social and Economic History Volume 12, Leuven University Press, 1990a.

Margo, Robert A., "The Incidence and Duration of Unemployment: Some Long-Term Comparisons," Economics Letters 32, January 1990b, 217-220.

Margo, Robert A., "The Microeconomics of Depression Unemployment," Journal of Economic History 51, June 1991, 333-341.

Margo, Robert A., "Employment and Unemployment in the 1930s," Journal of Economic Perspectives 7, Spring 1993, 41-60.

Margo, Robert A., "Labor Market Integration before the Civil War: New Evidence," Working paper, Vanderbilt University, June 1994.

Mathewson, Stanley B., Restriction of Output Among Unorganized Workers, New York: Viking, 1931.

Means, Gardiner C., "Industrial Prices and Their Relative Inflexibility," U.S. Senate Document 13, 74th Congress, 1st Session, Washington, D.C. 1935.

Meltzer, Allan, "Information, Sticky Prices, and Macroeconomic Foundations," Working Paper, CarnegieMellon University, October 1994. 
Mendoza, Enrique, "Real Business Cycles in a Small Open Economy," American Economic Review 81, September 1991, 797-818

Metcalfe, Stan, "On Diffusion, investment and the Process of Technological Change," in Enrico Deiaco, Erik Hornell, and Graham Vickery, eds., Technology and Investment: Crucial Issues for the 1990s, London: Pinter, 1990, 17-38.

Miron, Jeffrey A., "Financial Panics, the Seasonality of the Nominal Interest Rate, and the Founding of the Fed," American Economic Review 76, March 1986, 125-140.

Miron, Jeffrey A. and Romer, Christina D., "A New Monthly Index of Industrial Production, 1884-1940," Jowrnal of Economic History 50, June 1990, 321-332.

Mitchell, Daniel J.B., "Wage Flexibility: Then and Now," Industrial Relations 24, Spring 1985, $266-79$.

Mitchell, Wesley C., What Happens During Business Cycles: A Progress Report, New York: National Bureau of Economic Research, 1951.

Moore, Geoffrey H. and Zarnowitz, Victor, "The Development and Role of the National Bureau of Economic Research's Business Cycle Chronologies," in Robert J. Gordon, ed., The American Business Cycle: Continuity and Change, Chicago: University of Chicago Press, 1986, 735-779.

Murphy, Kevin M., Shleifer, Andrei, and Vishny, Robert W., "Industrialization and the Big Push," Journal of Political Economy 97, October 1989, 1003-1026.

Neal, Larry, "Why Crowding Out Did Not Occur and Crowding In Did: A New Look at the History of the British National Debt," Working paper, University of Illinois.

North, Douglass C., The Economic Growth of the United States, 1790-1860, Englewood Cliffs, NJ: Prentice-Hall, 1961.

North, Douglass C., Institutions, Institutional Change and Economic Performance, Cambridge: Cambridge University Press, 1990.

O'Brien, Anthony Patrick, "Factory Size, Economies of Scale, and the Great Merger Wave of 1898-1902," Journal of Economic History 48, September 1988, 639-649.

O'Brien, Anthony Patrick, "A Behavioral Explanation for Nominal Wage Rigidity during the Great Depression," Quarterly Journal of Economics 104, November 1989, 719-735.

Obstfeld, Maurice, "The Adjustment Mechanism," in Michael D. Bordo and Barry Eichengreen, eds., $A$ Retrospective on the Bretton Woods System: Lessons for International Monetary Reforms, Chicago: University of Chicago Press, 1993, 201-256.

Olmstead, Alan, and Rhode, Paul, "Rationing Without Government: The West Coast Gas Famine of 1920, American Economic Review 75, December 1985, 1044-1055.

Ozanne, Robert, Wages in Practice and Theory: McCormick and International Harvester, 1860-1960, Madison, Wisconsin: University of Wisconsin Press, 1968. 
Plosser, Charles I., "Understanding Real Business Cycles," Journal of Economic Perspectives 3, Summer 1989, 51-77.

Raff, Daniel M.G., "Wage Determination Theory and the Five-Dollar Day at Ford," Journal of Economic History 48, June 1988, 387-399.

Ransom, Roger, Sutch, Richard and Carter, Susan, "Reestimating the Annual Unemployment Rate Series for the United States, 1890-1940," Research in Economic History 14, 1992, 293-299.

Rees, Albert, Real Wages in Manufacturing, 1890-1914, Princeton: Princeton University Press, 1961.

Romer, Christina, "Spurious Volatility in Historical Unemployment Data," Journal of Political Economy 94, February 1986a, 1-37.

Romer, Christina, "Is the Stabilization of the Postwar Economy a Figment of the Data?" American Economic Review 76, June 1986b, 314-334.

Romer, Christina, "The prewar Business Cycle reconsidered: New Estimates of Gross National product, 1869-1908," Journal of Political Economy 97, February 1989, 1-37.

Romer, Christina, "Remeasuring Business Cycles," Journal of Economic History 54, September 1994, 573-609.

Romer, David, "The New Keynesian Synthesis," Journal of Economic Perspectives 7, Winter 1993, 5-22.

Rosenbloom, Joshua L., "Labor Market Institutions and the Geographic Integration of Labor Markets in the Late Nineteenth Century United States," Ph.D. Dissertation, Stanford University, 1988.

Rosenbloom, Joshua L., "One Market or Many? Labor Market Integration in the Late Nineteenth-Century United States," Journal of Economic History 50, March 1990, 85-107.

Rotemberg, Julio J. and Woodford, Michael, "Markups and the Business Cycle," in Olivier Jean Blanchard and Stanley Fischer, eds., NBER Macroeconomic Annual 1991, Cambridge: MIT Press, 1991.

Sachs, Jeffrey, "The Changing Cyclical Behavior of Wages and prices: 1890-1976," American Economic Review 70, March 1980, 78-90.

Salter, W.E.G., Productivity and Technical Change, Cambridge: Cambridge University Press, 1960.

Sargent, Thomas J., "The Ends of Four Big Inflations," Working paper, University of Minnesota, 1981 a.

Sargent, Thomas J., "Stopping Moderate Inflations: The Methods of Poincare and Thatcher," Working paper, University of Minnesota, $1981 \mathrm{~b}$.

Schumpeter, Joseph A., Business Cycles: A Theoretical, Historical and Statistical Analysis of the Capitalistic Process, New York: McGraw-Hill, 1939.

Shapiro, Matthew D., and Watson, Mark W., "Sources of Business Cycle Fluctuations," NBER Macroeconomics Annual, 1988, 111-156. 
Shaw, William Howard, Value of Commodity Output Since 1869, New York: National Bureau of Economic Research, 1947.

Shergold, Peter R., "Wage Rates in Pittsburgh during the Depression of 1908," Journal of American Studies 9, August 1975, 163-188.

Shister, Joseph, "A Note on Cyclical Wage Rigidity," American Economic Review 34, March 1944, 111-116.

Simkovich, Boris A., "Agriculture and Industry in the New Republic: Explaining America's Structural Transformation, 1800-1860," Working Paper, Harvard University, July 1994.

Smith, Bruce D., "Some Colonial Evidence on Two Theories of Money: Maryland and the Carolinas," Journal of Political Economy 93, December 1985a, 1178-1211.

Smith, Bruce D., "American Colonial Monetary Regimes: The Failure of the Quantity Theory of Money and Some Evidence in Favor of an Alternate View," Canadian Journal of Economics 18, August 1985b, 531-565.

Snowden, Kenneth, "Three Essays on the American Capital Market, 1870-1913," Ph.D. Dissertation, University of Wisconsin-Madison, 1984.

Snowden, Kenneth, "The Evolution of Interregional Mortgage Lending Channels, 1870-1940," Working Paper, Harvard University, 1993.

Snowden, Kenneth, and Abu-Saba, Nidal, "Why Did Late Nineteenth Century American Mortgage Banking Fail?", Working Paper, Harvard University, 1994.

Sokoloff, Kenneth L., "Inventive Activity in Early Industrial America: Evidence from Patent Records, 1790-1846," Journal of Economic History 48, December 1988, 813-850.

Solomou, Solomos, Phases of Economic Growth, 1850-1973: Kondratieff Waves and Kuznets Swings, Cambridge: Cambridge University Press, 1987.

Solow, Robert M., "Distribution in the Long and Short Run," in Jean Marchal and Bernard Ducros, eds., The Distribution of National Income, New York: St. Martin's Press, 1968.

Spencer, Austin, "Relative Downward Industrial price Flexibility, 1870-1921," Explorations in Economic History 14, January 1977, 1-19.

Stiglitz, Joseph D., "Theories of Wage Rigidities," in J. Butkiewicz, ed., Keynes' Economic Legacy: Contemporary Economic Theories, New York: Praeger, 1986.

Sundstrom, William A., "Was There a Golden Age of Flexible Wages?: Evidence from Ohio Manufacturing, 1892-1910," Journal of Economic History 50, June 1990, 309-320.

Sundstrom, William A., "Rigid Wages or Small Equilibrium Adjustments?: Evidence from the Contraction of 1893," Explorations in Economic History 29, October 1992, 430-455. 
Sundstrom, William A., and Rosenbloom, Joshua L., "Occupational Differences in the Dispersion of Wages and Working Hours: Labor Market Integration in the United States, 1890-1903," Explorations in Economic History 30, October 1993, 379-408.

Sylla, Richard, "Federal Policy, Banking Market Structure, and Capital Mobilization in the United States, 1863-1913," Journal of Economic History 29, December 1969.

Taussig, Frank William, A Tariff History of the United States, New York: G.P. Putnam's Sons, 1931.

Temin, Peter, Lessons from the Great Depression, Cambridge, MA: The MIT Press, 1989.

Thomas, Brinley, Migration and Economic Growth, Cambridge: Cambridge University Press, 1954.

Tobin, James, "Price Flexibility and Output Stability: An Old Keynesian View," Journal of Economic Perspectives 7, Winter 1993, 45-65.

Towne, Marvin W. and Rasmussen, Wayne D., "Farm Gross Product and Gross Investment in the Nineteenth Century," in Trends in the American Economy in the Nineteenth Century, NBER Studies in Income and Wealth, Vol. 24, New York: Columbia University Press, 1960, 255-315.

United States Bureau of the Census, Historical Statistics of the United States, Washington: Government Printing Office, 1975.

United States Bureau of Labor Statistics, "Summary of Manufacturing Production Workers Earnings Series, 1939-1968," Bulletin 1616, Washington, D.C., 1969.

United States Bureau of Labor Statistics, "Consumer Price Index Detailed Report," March 1992.

United States Council of Economic Advisers, Economic Report of the President, Washington: Government Printing Office, various years.

von Tunzelmann, G.N., Steam Power and British Industrialization to 1860, Oxford: Oxford University Press, 1978.

Wachter, Michael, "Cyclical Variation in the Interindustry Wage Structure," American Economic Review 60, March 1970, 75-84.

Wallis, John J., "Employment in the Great Depression: New Data and Hypotheses," Explorations in Economic History 26, January 1989, 45-72.

Warren, G.F. and Pearson, F.A., "Wholesale Prices in the United States for 135 Years, 1797 to 1932," Cornell University Agricultural Experiment Station, Memoir 142, November 1932.

Watson, Mark W., "Business-Cycle Durations and Postwar Stabilization of the U.S. Economy," American Economic Review 84, March 1994, 24-46.

Weinstein, Michael M., "Some Macroeconomic Impacts of the National Industrial Recovery Act, 1933-1935," in Karl Brunner, ed., The Great Depression Revisited, Rochester Studies in Economics and Policy Issues, Volume 2, 1981. 
Weir, David R., "The Reliability of Historical Macroeconomic Data for Comparing Cyclical Stability," Journal of Economic History 46, June 1986, 353-365.

Weir, David R., "A Century of U.S. Unemployment, 1890-1990: Revised Estimates and Evidence for Stabilization," Research in Economic History 14, 1992, 301-346.

Wheelock, David C., "The Strategy, Effectiveness, and Consistency of Federal Reserve Monetary Policy, 1924-1933," Explorations in Economic History 26, October 1989, 453-476.

Wheelock, David C., "Member Bank Borrowing and the Fed's Contractionary Monetary Policy during the Great Depression," Journal of Money, Credit and Banking 22, November 1990, 409-426.

Wheelock, David C., and Kumbhakar, Subal C., "'The Slack Banker Dances:' Deposit Insurance and Risk-Taking in the Banking Collapse of the 1920s," Explorations in Economic History 31, July 1994, 357375.

White, Eugene N., The Regulation and Reform of the American Banking System, 1900-1929, Princeton: Princeton University Press, 1983.

White, Eugene N., "Voting for Costly Regulation: Evidence from Banking Referenda in Illinois, 1924," Southern Economic Journal 51, 1984, 1084-1098.

White, Eugene N., "Before the Glass-Steagall Act: An Analysis of the Investment Banking Activities of National Banks," Explorations in Economic History 23, January 1986, 33-55.

Wicker, Elmus, "A Reconstruction of the Gold and Banking Crises in 1931," Working paper, Indiana University, October 1993.

Wood, Elmer, English Theories of Central Banking Control, 1819-1858, Cambridge, MA: Harvard University Press, 1939.

Wright, Gavin, "Cheap Labor and Southern Textiles Before 1880," Journal of Economic History 39, September 1979, 655-680.

Wright, Gavin, "Cheap Labor and Southern Textiles, 1880-1930," Quarterly Journal of Economics 96, November 1981, 605-629.

Wright, Gavin, Old South, New South, New York: Basic Books, 1986.

Wright, Gavin, "The Origins of American Industrial Success, 1879-1940," American Economic Review 80, September 1990, 651-668.

Zarnowitz, Victor, Business Cycles: Theory, History, Indicators, and Forecasting, Chicago: University of Chicago Press, 1992. 


\section{NOTES}

1. Despite Friedman and Schwartz's comprehensive coverage of financial institutional history, ironically, the message of their treatise is that institutions only matter through their effect on the money stock. Other work, discussed below, is at odds with that view.

2. The distinction between historical macroeconomics and macroeconomic history is also emphasized in a precursor to this article, Eichengreen (1987).

3. See David (1991) for a review of the theoretical literature on path dependence and its applicability to economic history.

4. United States Bureau of the Census (1975): nonagricultural sectoral employment series D127-141, total employment series D5, farm employment series K174.

5. Greenwood, Hercowitz and Huffman (1988) show that one can construct utility and production functions that allow consumption to move procyclically in response to a change in the expected productivity of investment, but this appears to be a knife-edge result.

6. Another explanation for procyclical productivity is endogenous technological improvement in response to aggregate-demand shocks. We argue that endogenous technological improvement through increasing returns, learning, and "shake out" of low-productivity firms were important historically for over long periods of time and were relevant for understanding Kuznets cycles. But given the long lags of technological change, endogenous technological improvement was likely not very important for year-toyear fluctuations.

7. Money supply (currency held by the public plus bank deposits) from Friedman and Schwartz (1963, Table A-1). Wholesale prices from Warren and Pearson (1932, Table 1). Consumer prices from Rees (1961, Table 22) and U.S. Bureau of Labor Statistics (1992).

8. Interestingly, similar evidence for the nineteenth century (reported in Bowley, 1904) was cited by Keynes $(1931,165)$, and formed the basis for his view that nominal wage rigidity was greater than nominal price rigidity:

It is decade from 1886 to 1896 with which I am concerned, and chiefly with the years of declining prices from 1890 to 1896 . Between 1890 and 1896 Sauerbeck's Wholesale Index fell about 18 per cent, and the Economist's about 14 percent....But there was no evidence of Income Deflation. On the contrary, rates of money wages were moving slightly upwards, and other money-incomes were also on the up-grade, apart from a slight sagging in 1892-93 owing to the very severe unemployment in those years...(pp. 164-165).

9. Intersectoral substitution is not the only explanation for higher historical labor turnover in manufacturing. Margo (1990a) argues that some of the relatively short duration of historical employment can be attributed to changes in the composition of the workforce, and changes in unemployment relief policies in the 1930 .

10. In one fascinating account, Harley (1982) argues that the collapse of railroad cartels helped to set in motion the railroed and construction boom of the 1880 s. According to this argument, so long as the railroads were able to cooperate, it was profitable for development to follow a regular, deliberate process. Once cooperation broke down, the only way to seize market share was to build ahead of demand. 
11. Even more fundamentally, scholars disagree over whether long swings reflected an endogenous cyclical process - in which cycles of similar duration repeated naturally - or a shock-and-propagation process, in which the timing and duration of the cycles reflected unique and unpredictable disturbances. Easterlin's (1966) emphasis on immigration led him to argue that "echo effects" may have explained the average duration of the cycle - a wave of immigrants would produce a new generation of frontier builders roughly at 18-year intervals.

12. That is not to say that investment banking was unimportant in the United States as a means of financing industry. But despite the efforts and successes of investment banks in reducing some firms' costs of external finance (DeLong, 1991), such financing was confined to the largest, most mature firms in the economy, and new issues typically were restricted to senior claims against those firms (bonds and preferred stock) because of the high cost of placing common stock (Calomiris and Raff, 1994).

13. To some extent, especially in New York, deposits on foreign banks, wired via the trans-Atlantic cable, may have been a cheaper means to introduce reserves to the U.S. banking system. But, as Calomiris and Hubbard (1994b) point out, there were limitations to the substitutability between foreign bank balances and gold, particularly given the risk of runs on banks.

14. This was not true of the waves of banking failures and bank runs during the Great Depression (Wicker, 1993). These began with regional problems in the South and Midwest, associated with severe deflation and exposure by those regions' banks to loan losses. Only later did problems spread to financial centers in the East and abroad. Great Depression banking problems also occurred near a business cycle trough, while national banking era panics coincided with cyclical peaks.

15. It is important to note that many, possibly most, bank failures during the 1930 s did not coincide with "runs" or "panics." Many banks failed as the result of isolated insolvencies in the wake of continuing deterioration in their particular assets. Panics or runs did occur, nationally and regionally, during the 1930 s, but only as occasional punctuation points in the general trend of asset value decline and failure. Thus it would be premature, and probably incorrect, to attribute most of the bank failures of the 1930s to panic episodes. For recent research trying to measure the importance of general runs on banks for producing bank failure, see Wicker (1993) and Calomiris and Mason (1994).

16. In the face of new competitive pressures on American banks, and the failures of many banks and thrifts in the 1980s, branching limitations and limits on the powers of commercial banks have been relaxed recently. In many ways, this process mirrors the branching and merger wave in banking during the 1920s. This illustrates how regulatory reform typically requires extreme circumstances. 


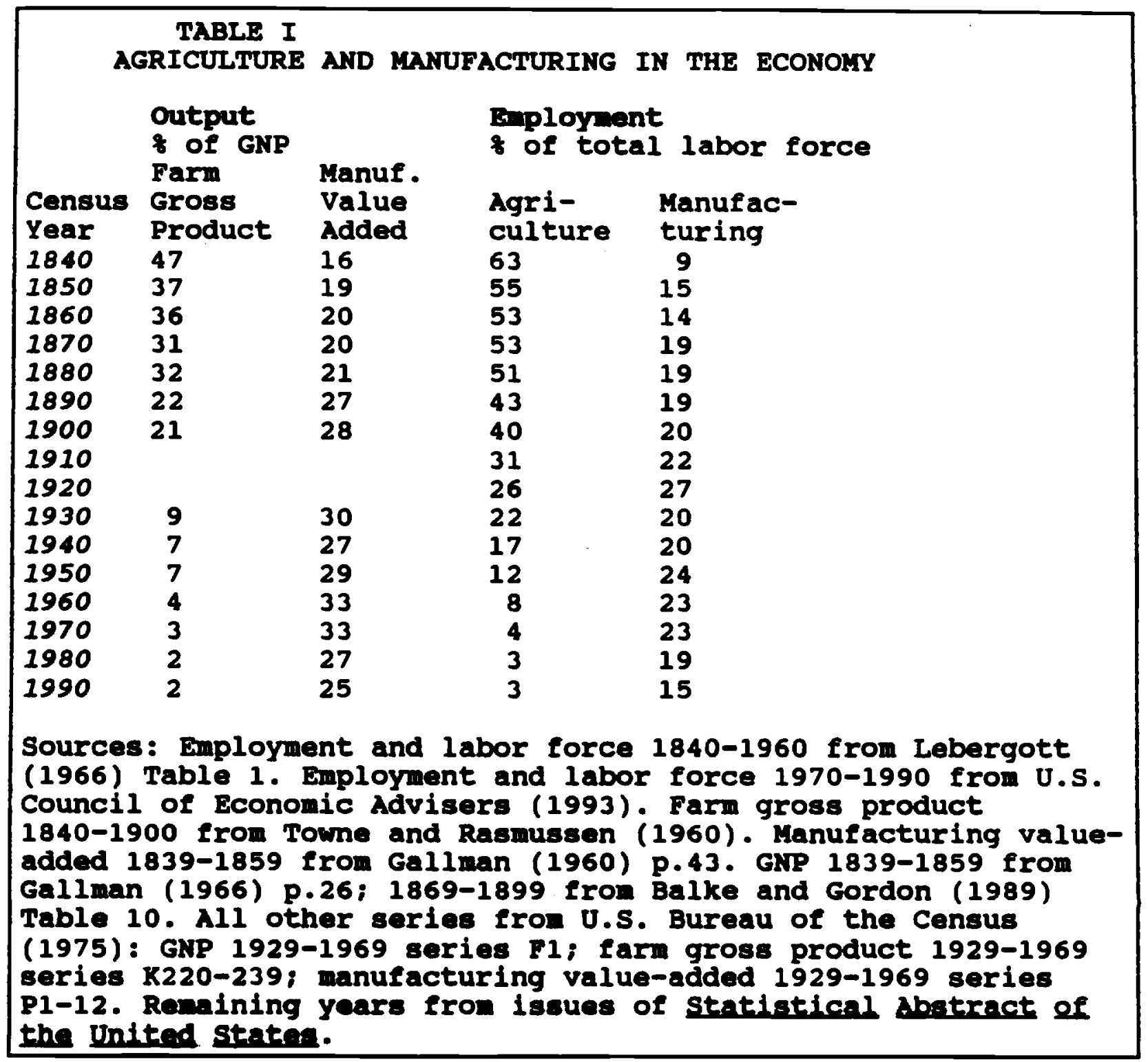


II) CHANGES IN PRICE BEHAVIOR

$p \quad$ Log Wholesale price index

$y \quad$ Log Industrial production

1869-1914 Frickey Manufacturing Output

1949-1990 FRB Materials Production

$\hat{x}$ Hodrick-Prescott trend in variable

Specifications

(1) Inflation on Output Deviation, Lagged Inflation

$$
\left(p_{t}-p_{t-1}\right)=\alpha+\beta\left(y_{t}-\hat{y}_{t}\right)+\gamma\left(p_{t-1}-p_{t-2}\right)
$$

(2) Price Deviation on Output Deviation

$$
p_{t}-\beta_{t}=\delta\left(y_{t}-\gamma_{t}\right)
$$

(3) Inflation Change on Output Change

$$
p_{t}-p_{t-1}=\alpha+\epsilon\left(y_{t}-y_{t-1}\right)
$$

(4) Ratio, Inflation Change over Change in Output Deviation, NBER Downturns

$$
\zeta=\frac{\left(p_{t}-p_{t-1}\right)-\left(p_{t-1}-p_{t-2}\right)}{\left(y_{t}-y_{t}\right)-\left(y_{t-1}-y_{t-1}\right)}
$$

(5) Inflation Change on Output Deviation

$$
\left(p_{t}-p_{i-1}\right)-\left(p_{t-1}-p_{t-2}\right)=\alpha+\eta\left(y_{t}-y_{t}\right)
$$
(1)
(2)
(3)
(4)
$\epsilon \quad \zeta$

B $\quad \begin{array}{cc}Y & 6 \\ \text { (t-statistics) }\end{array}$

Historical Patterns, Pre-1914 versus Post-1947
$1869-$
0.3501
0.0987
0.4505
0.2844
0.772
0.2171
1914
$(3.630)$
$(0.738)$
(5.306)
(3.293)
(1.622)
1949-
0.3516
$0.5790 \quad-0.2211$
$-0.0039$
0.047
0.3929
1990
$(3.998)$
$(5.065)(-1.289)$
$(-0.039)$
$(3.929)$
1949- 0.3189
1990
$(3.790)$
$0.4932-0.2328$
0.0327
$(0.361)$
0.196
0.3828
(3.790) 


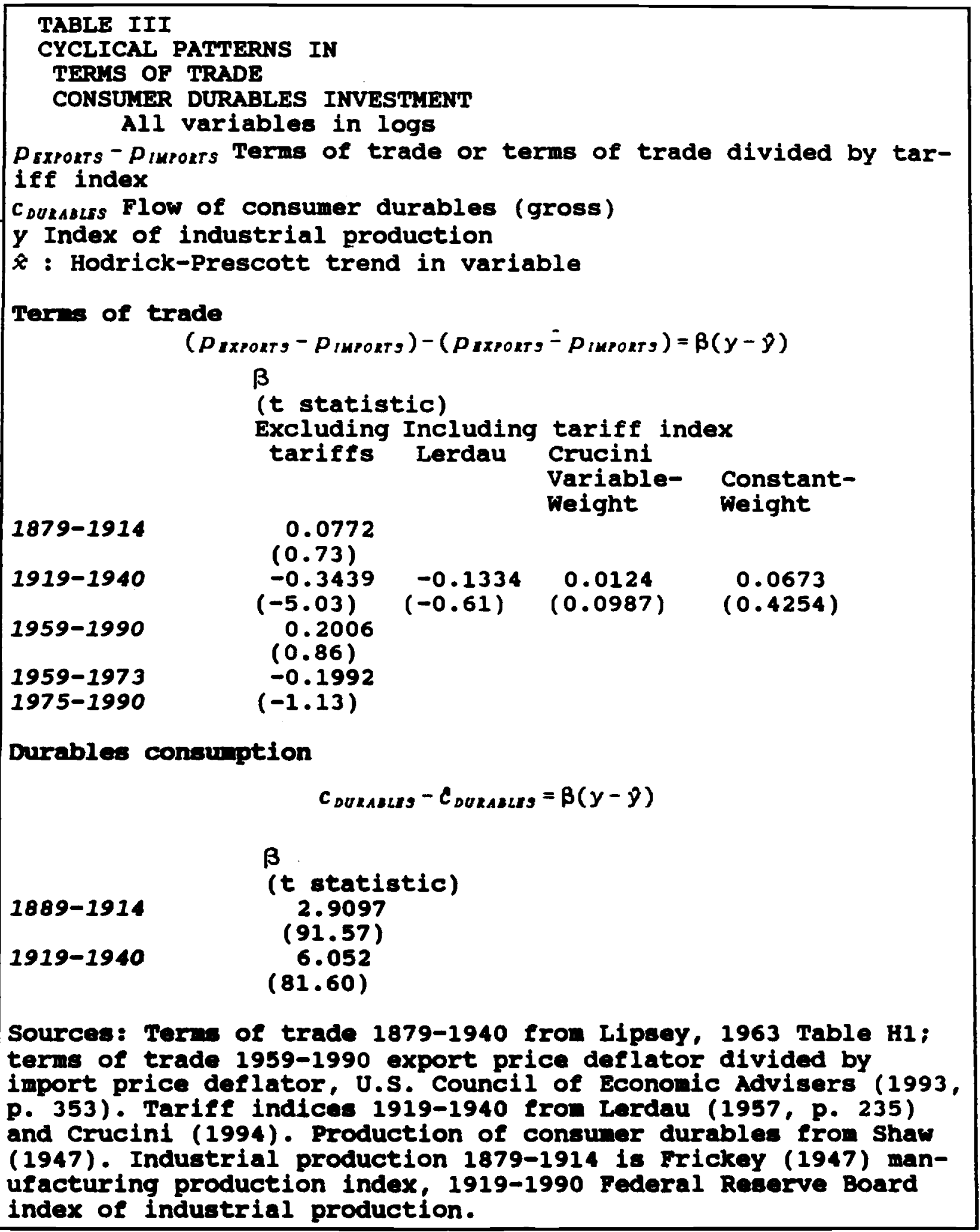

